\title{
Synthesis, Spectroscopic and Computational Studies of Some Metals Chelates with Chromene-2-one and Pyrazine-Based Ligands
}

\author{
Taghreed Mohy Al-Deen Musa ${ }^{1}$, Mahmoud Najim Abid Al-Jibouri ${ }^{1, *}$, \\ Bayader Fadhil Abbas ${ }^{1}$, and Nahid Hasani ${ }^{2}$ \\ ${ }^{1}$ Department of Chemistry, College of Science, Mustansiriyah University, Baghdad, Iraq \\ ${ }^{2}$ Department of Inorganic Chemistry, Faculty of Chemistry, University of Mazandaran, Babolsar, Iran
}

\author{
*Corresponding author: \\ email: \\ mahmoud_inor71@uomustansiriyah.edu.iq
}

Received: February 7, 2019

Accepted: July 18, 2019

DOI: $10.22146 /$ ijc. 43857

\begin{abstract}
The present paper deals with the synthesis of cobalt(II), nickel(II), copper(II) and cadmium(II) complexes with two bidentate ligands, $L^{1}$ (3(quinoxaline-2-yl)-coumarin) and $L^{2}$ (2-methylene-2H-chromene-3-(methyl carbonimidic)thioanhydride). The $L^{1}$ ligand was prepared by treating $\omega$-bromo-3acetylcoumarin with 1,2-phenylenediamine whereas the ligand $L^{2}$ was prepared through substitution reaction of $\omega$-bromo-3-acetylcoumarin with potassium thiocyanate in ethanol medium. The confirmation of the structures for $L^{1}$ and $L^{2}$ were done by (C.H.N.S.) elemental analysis, FT-IR, NMR and mass spectra. The metal complexes of cobalt(II), nickel(II), copper(II) and cadmium(II), with $L^{1}$ and $L^{2}$, were prepared and isolated in the solid state and then characterized by (C.H.N.M) elemental analysis, proton and carbon-13 NMR, FT-IR and mass spectra. Furthermore, the thermal analysis (TG-DSC) for some complexes assisted us in the elucidation of the suggested structures of complexes and confirmed their thermal stability. The results obtained from elemental analysis, magnetic susceptibility and thermal analysis confirmed that all metal complexes were formed in 2:1 molar ratio of ligand to metal with octahedral structures except cadmium(II) complexes which were in a tetrahedron geometry with 1:1 mole ratio. The complexes are found to be soluble in DMF and DMSO. The results obtained from TG-DSC analysis revealed that the metal complexes were thermally stable with point decomposition over $350{ }^{\circ} \mathrm{C}$. The DFT/TDDFT calculations were carried out to provide the electronic structures and spectra of the compounds.
\end{abstract}

Keywords: transition metal complexes of pyrazine ligands; theoretical studies of metal complexes

\section{- INTRODUCTION}

The metal complexes possessing chromen-2-one and pyrazine rings have gained attention in the field of the pharmaceutical industry [1-3]. It is well-known from literature, the transition elements complexes with bidentate Lewis bases of coumarin have known during the last decades as antitumor agents [4-5]. As well as the semicarbazone of pyrazine derivatives with their metal chelate have adopted as active materials in the treatment of rare diseases [6-7]. The coordination chemistry of coumarin ligand has great interesting in the field of colorimetric determination of trace amounts of heavy metals [8]. The antimicrobial activity of coumarin nucleus and antioxidant activity [9] has a great important effect like antibacterial, antithrombotic and Esculetin, a coumarin compound can inhibit the growth of human leukemia [10]. As it has been investigated in the literature, the biological activity of some chromene derivatives are significantly enhanced by binding to metal ions [11-12]. In continuation with the description of new metal complexes of quinoxaline and coumarin ligands, we report the synthesis, characterization and thermal study of some first-row transition metal 
complexes with two ligands derived from 3-bromoacetylcoumarin-2-one. The gaining comprehensive insight into the properties and chemical behavior of the transition metal complexes, the quantum chemical calculations using density functional theory (DFT) and timedependent density functional theory (TDDFT) have been carried out to authenticate the plausible geometry of the titled compounds. Here in, the electronic structures, also electronic excitations together with the nature of the frontier orbital are interpreted by theoretical calculations.

\section{- EXPERIMENTAL SECTION}

\section{Materials}

All chemicals were of reagent grade, and solvents were dried and distilled before use according to the standard procedures. 3-Acetylcoumar-2-one was purchased from Sigma-Aldrich company and other starting materials like potassium thiocyanate and 1,2phenylenediamine were supported from laboratories of the Chemistry Department, College of Science, Mustansiriyah University. The hydrated chlorides $\mathrm{CoCl}_{2} \cdot 6 \mathrm{H}_{2} \mathrm{O}, \mathrm{NiCl}_{2} \cdot 6 \mathrm{H}_{2} \mathrm{O}, \mathrm{CuCl}_{2} \cdot 2 \mathrm{H}_{2} \mathrm{O}$ and $\mathrm{CdCl}_{2} \cdot 2 \mathrm{H}_{2} \mathrm{O}$ and were purchased from Alfa company, and were used without further purification as received. The measurements of molar conductivity were made on a Hanna conductivity bridge with a cell constant $1.0 \mathrm{~cm}^{-1}$. The magnetic susceptibility measurements were made on Gouy's balance at room temperature using $\mathrm{Hg}\left[\mathrm{Co}(\mathrm{SCN})_{4}\right]$ as calibrating on Sherwood magnetic balance. The FT-IR spectra were recorded in a $\mathrm{KBr}$ and $\mathrm{CsI}$ matrix using a Shimadzu FTIR spectrometer model 983 . The electronic spectra in the range $(200-1000 \mathrm{~nm})$ were done for all complexes and the free ligands complexes in DMF and ethanol solutions were scanned on Carry 2390 Instrument. TG and DSC (Differential Scanning Colorimetric) thermograms in different ranges were carried out at (R.T) heating rate = $10^{\circ} \mathrm{C} / \mathrm{min}$ (Linseis STA PT-1000) were run on service laboratories of Ibn-Haithum college of education, University of Baghdad. The metal contents of the complexes were determined by flame atomic absorption spectroscopy on A Spect LS/FL 1.3.0.0 model. The magnetic susceptibility of the solid complexes was measured according to Faraday's method using auto Magnetic susceptibility Balance Sherwood Scientific. The mass spectra were performed using the instrument: GC MS-QP 2010 VLTRA, University of Mustansiriyah.

\section{Procedure}

\section{Synthesis of $\omega$-bromo-3-acetylcoumarin}

The preparation of bromo-3-acetylcoumarin was carried out according to the method described in the literature [12], (Scheme 1).

\section{Synthesis of $L^{1}$ ligand}

A solution of ( $5 \mathrm{mmol}$ ) $\omega$-bromo-3-acetylcoumarin and (5 mmol) 1,2-phenylenediamine in absolute methanol $(20 \mathrm{~mL})$ was refluxed for $4 \mathrm{~h}$. The solid obtained was filtered, washed with ethanol and dried under vacuum. The crude product was recrystallized from ethanol/ benzene mixture to give compound 11 as pale brown crystals, (Scheme 2). Chem. Anal. Calc. for $\mathrm{C}_{17} \mathrm{H}_{12} \mathrm{O}_{2} \mathrm{~N}_{2}$, $L^{1}$ (MW: 276.29): C, 73.90; H, 4.38; N, 10.14. Found: C, 73.09; H, 4.23; N, 10.19. Yield 77\%, decomposition point: $\left(148-150{ }^{\circ} \mathrm{C}\right)$. IR $v(\mathrm{KBr} \mathrm{disc}) / \mathrm{cm}^{-1}: 3088,3455,3292$, 1649, 1622, 1580, 1554.

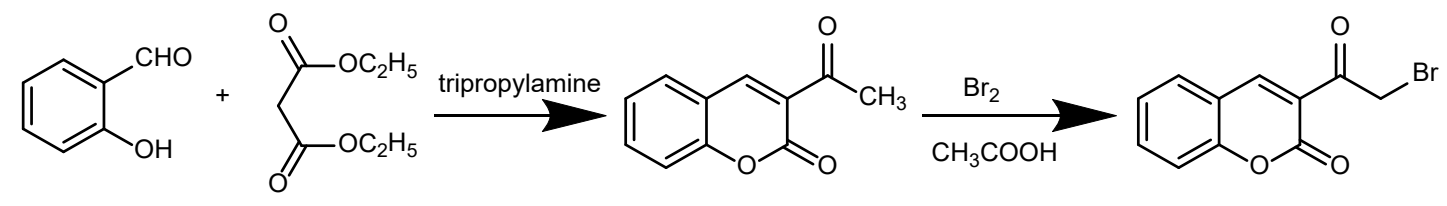

Scheme 1. Synthesis of $\omega$-bromo-3-acetylcoumarin

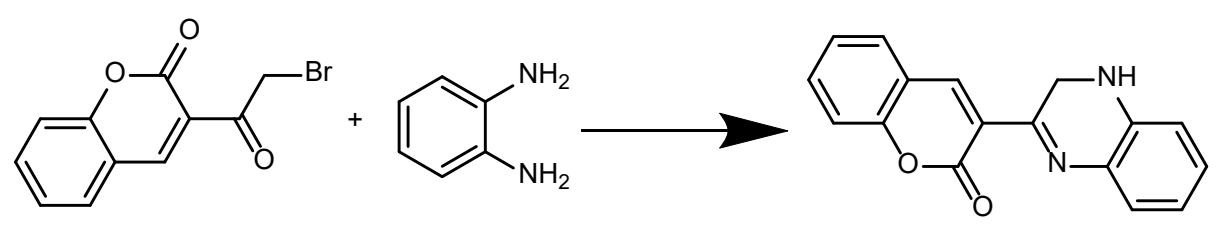

Scheme 2. Synthesis of $\left[\mathrm{L}^{1}\right]$ 


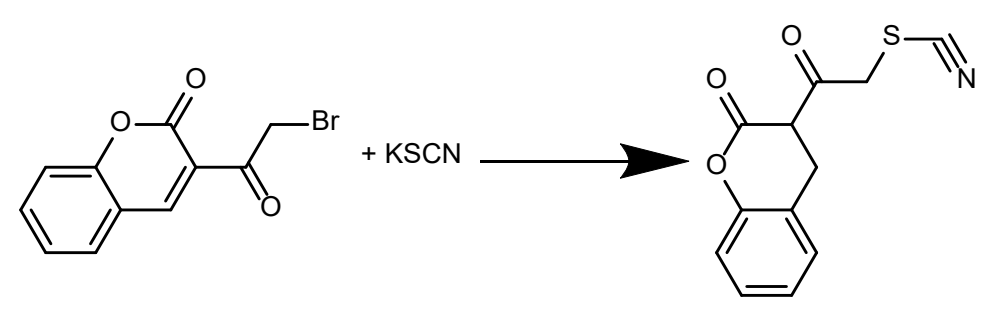

Scheme 3. Synthesis of $\mathrm{L}^{2}$

\section{Synthesis of $L^{2}$ ligand}

A solution of compound (2) $(10 \mathrm{mmol})$ in methanol $(40 \mathrm{~mL})$ was refluxed with potassium thiocyanate $(10$ $\mathrm{mmol}$ ) for $3 \mathrm{~h}$. The solid formed on cooling filtered off, washed with ethanol and dried under vacuum. The product was then recrystallized from acetic acid to afford brown needles, (Scheme 3). Chem. Anal. Calc. for $\mathrm{C}_{12} \mathrm{H}_{7} \mathrm{O}_{3} \mathrm{NS}, \mathrm{L}^{2}$; (MW: 245.25): C, 58.77; H, 2.88; N, 5.71; S, 13.07. Found: C, 58.18; H, 2.52; N, 5.98; S, 13.54. Yield 90\%, Decomposition point: $\left(138-140{ }^{\circ} \mathrm{C}\right) . \mathrm{IR} \vee(\mathrm{KBr}$ $\mathrm{disc}) / \mathrm{cm}^{-1}: 3117$, 3354, 1649, 1606, 1556.

\section{Synthesis of the metal complexes}

[Co( $\left.\left(\mathrm{L}^{1}\right)_{2} \mathrm{Cl}_{2}\right] \mathrm{H}_{\mathbf{2}}$ O. $\left[\mathrm{C}_{34} \mathrm{H}_{26} \mathrm{O}_{5} \mathrm{~N}_{4} \mathrm{Cl}_{2} \mathrm{Co}\right.$ ]; (Mwt: 698.42): C, 58.47; H, 3.46; N, 8.02; Cl, 10.15; Co, 8.44\%. Found: C, 58.02; H, 3.16; N, 8.27; Cl, 9.22; Co, 8.17\%. M.P: (182$\left.184{ }^{\circ} \mathrm{C}\right) . \mathrm{IR} \vee(\mathrm{KBr} \operatorname{disc}) / \mathrm{cm}^{-1}: 3650,3023,2933,1649$, 1593-1559, 424-472. $\Lambda_{\mathrm{m}} / \Omega^{-1} \mathrm{~cm}^{2} \mathrm{~mol}^{-1}$ (in DMF22). Color: brown.

[Ni( $\left.\left.\mathrm{L}^{1}\right)_{2} \mathrm{Cl}_{2}\right] \mathrm{H}_{2}$ O. $\left[\mathrm{C}_{34} \mathrm{H}_{26} \mathrm{O}_{5} \mathrm{~N}_{4} \mathrm{Cl}_{2} \mathrm{Ni}\right.$ ]; (Mwt.: 700.19): C, 58.49; H, 3.46; N, 8.79; Cl, 10.16; Ni, 8.02\%. Found: C, 58.17; H, 3.12; N, 8.92; Cl, 9.96; Ni, 7.89\%. M.P: (161$\left.163{ }^{\circ} \mathrm{C}\right)$. IR $\vee(\mathrm{KBr}$ disc $) / \mathrm{cm}^{-1}: 3440,3088,2987,1664-$ $1651,1622,1554,542,455 . \Lambda_{\mathrm{m}} / \Omega^{-1} \mathrm{~cm}^{2} \mathrm{~mol}^{-1}$ (in DMF16). Color: brown.

[Cu( $\left.\left.\mathbf{L}^{1}\right)_{2} \mathrm{Cl}_{2}\right] \mathrm{H}_{2}$ O. $\left[\mathrm{C}_{34} \mathrm{H}_{26} \mathrm{O}_{5} \mathrm{~N}_{4} \mathrm{Cl}_{2} \mathrm{Cu}\right]$; (Mwt: 705.05): C, 64.40; H, 4.13; N, 8.84; Cu, 10.02\%. Found: C, 64.11; H, 3.98; N, 8.90; Cu, 9.95\%. M.P: $\left(198-200{ }^{\circ} \mathrm{C}\right)$. IR $\vee(\mathrm{KBr}$ $\mathrm{disc}) / \mathrm{cm}^{-1}: 3200-3600,3012,2901,1645,1622,1624,1585$, 1566, 1533, 511-559, 434-489. $\Lambda_{\mathrm{m}} / \Omega^{-1} \mathrm{~cm}^{2} \mathrm{~mol}^{-1}$ (in DMF31). Color: purple.

[Cd( $\left.\left.\mathbf{L}^{1}\right)_{2}\right] \mathrm{Cl}_{2} \cdot \mathrm{H}_{\mathbf{2}}$ O. $\left[\mathrm{C}_{34} \mathrm{H}_{26} \mathrm{O}_{5} \mathrm{~N}_{4} \mathrm{Cl}_{2} \mathrm{Cd}\right]$; (Mwt: 753.91): C, 64.40; H, 4.13; N, 8.84; Cd, 10.02\%. Found: C, 64.11; H, 3.98; N, 8.90; Cd, 9.95\%. M.P: (195-197 $\left.{ }^{\circ} \mathrm{C}\right)$. IR $v$ ( $\mathrm{KBr}$ $\mathrm{disc}) / \mathrm{cm}^{-1}:$ 3043, 2926, 1656, 1611, 1599, 1579, 546, 434. $\Lambda_{\mathrm{m}} / \Omega^{-1} \mathrm{~cm}^{2} \mathrm{~mol}^{-1}$ (in DMF 90). Color: purple.
[Co( $\left.\left(\mathrm{L}^{2}\right)_{2} \mathrm{Cl}_{2}\right] . \quad\left[\mathrm{C}_{24} \mathrm{H}_{14} \mathrm{O}_{6} \mathrm{~N}_{2} \mathrm{~S}_{2} \mathrm{Cl}_{2} \mathrm{Co}\right.$ ]; (Mwt: 620.35): C, 46.47; H, 2.27; N, 4.52; S, 10.34; Cl, 11.43; Co, 9.47\%. Found: C, 46.09; H, 2.11; N, 4.63; S, 10.22; Cl, 11.09; Co, 9.13\%. M.P: $\left(200-202{ }^{\circ} \mathrm{C}\right)$. IR $\vee(\mathrm{KBr} \mathrm{disc}) / \mathrm{cm}^{-1}: 3089$, $1606,1550,754,620 . \Lambda_{\mathrm{m}} / \Omega^{-1} \mathrm{~cm}^{2} \mathrm{~mol}^{-1}$ (in DMF 22). Color: Green.

[Ni( $\left.\left.\mathrm{L}^{2}\right)_{2} \mathrm{Cl}_{2}\right] 2 \mathrm{H}_{2}$ O. $\left[\mathrm{C}_{24} \mathrm{H}_{18} \mathrm{O}_{8} \mathrm{~N}_{2} \mathrm{~S}_{2} \mathrm{Cl}_{2} \mathrm{Ni}\right]$; (Mwt: 656.14): C43.93; H, 2.77; N, 4.27; S, 9.77; Cl, 10.81; Ni, 8.95\%. Found: C, 43.12; H, 2.09; N, 4.50; S, 9.22; Cl, 10.51; Ni, 8.21\%. M.P: (> 300 decomposition). IR $\vee(\mathrm{KBr}$ disc) $/ \mathrm{cm}^{-1}: 3340,3302,3120,1714,1630,1606,1558$, 1292, 1249, 624, 752. $\Lambda_{\mathrm{m}} / \Omega^{-1} \mathrm{~cm}^{2} \mathrm{~mol}^{-1}$ (in DMF 14). Color: Dark green.

[Cu(L $\left.\left(\mathrm{L}^{2}\right)_{2} \mathrm{Cl}_{2}\right] .\left[\mathrm{C}_{24} \mathrm{H}_{14} \mathrm{O}_{6} \mathrm{~N}_{2} \mathrm{~S}_{2} \mathrm{Cl}_{2} \mathrm{Cu}\right.$ ]; (Mwt: 624.96): C, 46.12; H, 2.26; N, 4.48; S, 10.26; Cl, 11.35; Cu, 10.17\%. Found: C, 45.91; H, 2.19; N, 4.66; S, 10.01; Cl, 11.12; Cu, 9.98\%. M.P: $\left(190-192{ }^{\circ} \mathrm{C}\right)$. IR $\vee(\mathrm{KBr} \mathrm{disc}) / \mathrm{cm}^{-1}: 3148$, 1728, 1718, 1635, 1606, 1560, 1244, 1166, 622, 758. $\Lambda_{\mathrm{m}} / \Omega^{-1} \mathrm{~cm}^{2} \mathrm{~mol}^{-1}$ (in DMF 19). Color: Silver.

[Cd( $\left.\left.\mathrm{L}^{2}\right)_{2}\right] \mathrm{Cl}_{2}$. [ $\left.\mathrm{C}_{24} \mathrm{H}_{14} \mathrm{O}_{6} \mathrm{~N}_{2} \mathrm{~S}_{2} \mathrm{Cl}_{2} \mathrm{Cd}\right]$; (Mwt: 673.82): C, 46.64; H, 2.80; N, 3.89; S, 8.89; Cl, 10.52; Cd, 15.59\%. Found: C, 46.13; H, 2.43; N, 3.98; S, 8.67; Cl, 10.21; Cd, 15.33\%. M.P: $\left(260-262{ }^{\circ} \mathrm{C}\right)$. IR $\vee(\mathrm{KBr} \mathrm{disc}) / \mathrm{cm}^{-1}: 3128$, $1728,1606,1590,1367,1290,725,634 . \Lambda_{\mathrm{m}} / \Omega^{-1} \mathrm{~cm}^{2} \mathrm{~mol}^{-1}$ (in DMF 120). Color: Grey.

\section{DFT procedure}

The electronic structures of the two series of Schiff base ligands, $\mathrm{L}^{1}$ and $\mathrm{L}^{2}$, and their metal complexes including $\mathrm{Co}(\mathrm{II}), \mathrm{Ni}(\mathrm{II}), \mathrm{Cu}(\mathrm{II})$ and $\mathrm{Cd}(\mathrm{II})$ have been optimized by density functional calculations (DFT) without any symmetry constraints, employing the Gaussian 09-package [13]. Frequency calculations were performed on all the optimized geometries to ensure the correct local minima. Al the calculations were carried out in the framework of the Becke three-parameter 
hybrid exchange and Lee-Yang-Parr correlation functional (B3LYP) together with a split-valence Pople basis set plus polarization and diffuse functions, 6$31+\mathrm{G}(\mathrm{d}, \mathrm{p})$ for $\mathrm{H}, \mathrm{C}, \mathrm{N}, \mathrm{O}, \mathrm{Cl}$ and $\mathrm{S}$ atoms and a double- $\zeta$ quality LANL2DZ basis set for metal atoms [14]. All the "inner electrons" of metal ions were replaced and described with a scalar relativistic electron core potential (ECP). Time-dependent density functional theory (TDDFT) calculations were performed to obtain the UV-Vis spectra and characterization of the frontier orbital, at B3LYP/6-31+G (d,p) level with the polarized continuum model (CPCM) in DMF solvent [15].

\section{- RESULTS AND DISCUSSION}

\section{Analysis and Physical Measurements}

All the complexes are sparingly soluble in common organic solvents but highly soluble in DMF and DMSO. The analytical data indicate that the complexes are mononuclear with a 2:1 molar ratio of ligand to the metal ion. The molar conductance in DMF for all complexes are in agreement of their structures with no remarkable conductivity due to absence of chloride counter ions while the cadmium(II) complexes were electrolyte in 2:1 ratio due to the motion of positively ionic complex and chloride counterion [16], and the complexes have the formula $\left[\mathrm{M}^{2}\left(\mathrm{~L}^{1}\right)_{2} \mathrm{Cl}_{2}\right] \cdot \mathrm{H}_{2} \mathrm{O}$ where $\mathrm{M}=\mathrm{Co}(\mathrm{II}), \mathrm{Ni}(\mathrm{II})$, $\left[\mathrm{Cu}\left(\mathrm{L}^{1}\right)_{2} \mathrm{Cl}_{2}\right]$ and $\left[\mathrm{Cd}\left(\mathrm{L}^{2}\right)_{2}\right] \mathrm{Cl}_{2} \cdot 2 \mathrm{H}_{2} \mathrm{O}$.

\section{Mass Spectra}

Fig. 1 clearly exhibits the molecular ion peak $\mathrm{m} / \mathrm{e}=$ 188 which agree well with the formula $\mathrm{C}_{11} \mathrm{H}_{8} \mathrm{O}_{3}$ [16]. As well as the bromination of 3-acetyl coumarin (A) by $\mathrm{Br}_{2}$ in chloroform solution leads to A2 derivative which its mass spectra in Fig. 2 displays a base peak at 267 that is consistent with $\mathrm{C}_{10} \mathrm{H}_{7} \mathrm{O}_{3} \mathrm{Br}$. However, the other peaks at 186 and 88 are extremely attributed to $\mathrm{M}-\mathrm{Br}+$ ion. The ring closure of 1,2-phenylenediamine with A2 derivative, Scheme 3 results in ligand L1 which shows molecular ion $\mathrm{m} / \mathrm{e}=274$ at relative intensity $100 \%$ then supports the proposed structure of the $\mathrm{L}^{1}$ ligand. On the other hand, the Fig. 3 represents the mass spectra of $\mathrm{L}^{2}$ ligand which shows absorptions at 245, 244, 192, 160, 128 and 81 that are assigned to $\mathrm{C}_{12} \mathrm{H}_{7} \mathrm{NSO}_{3}$ and fragments of M-SCN, M- $\mathrm{CH}_{2} \mathrm{SCN}$ and the base peak of $\mathrm{C}_{5} \mathrm{H}_{5} \mathrm{O}^{+}$respectively [17], Fig. 3.

\section{NMR Spectra}

The ${ }^{1} \mathrm{H}-\mathrm{NMR}$ spectra of the $\mathrm{L}^{1}$ ligand in a d6-DMSO solvent. Fig. 4 shows multiple signals at $6.5-7.90 \mathrm{ppm}$, corresponding to the eight protons aromatic ring protons

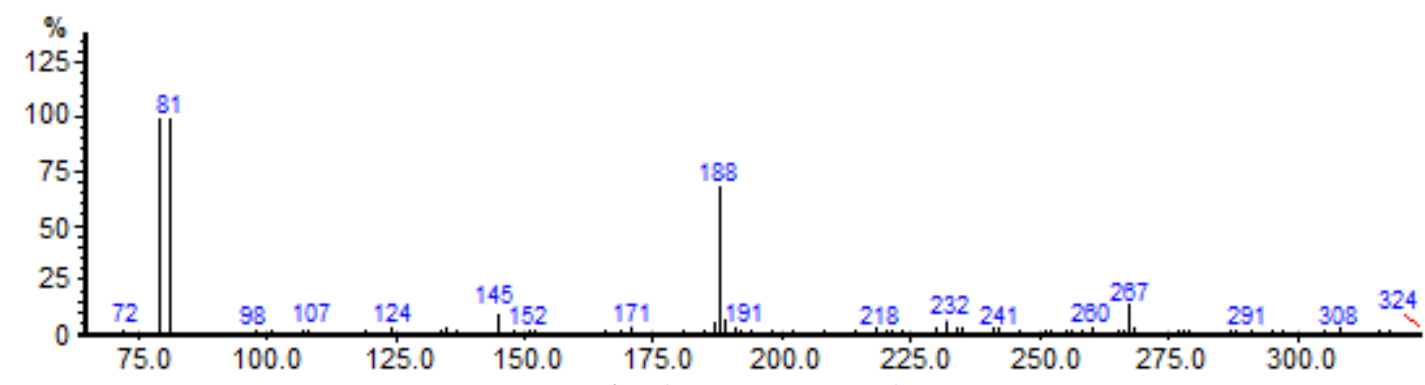

Fig 1. Mass of $\omega$-bromo-3-acetylcoumarin

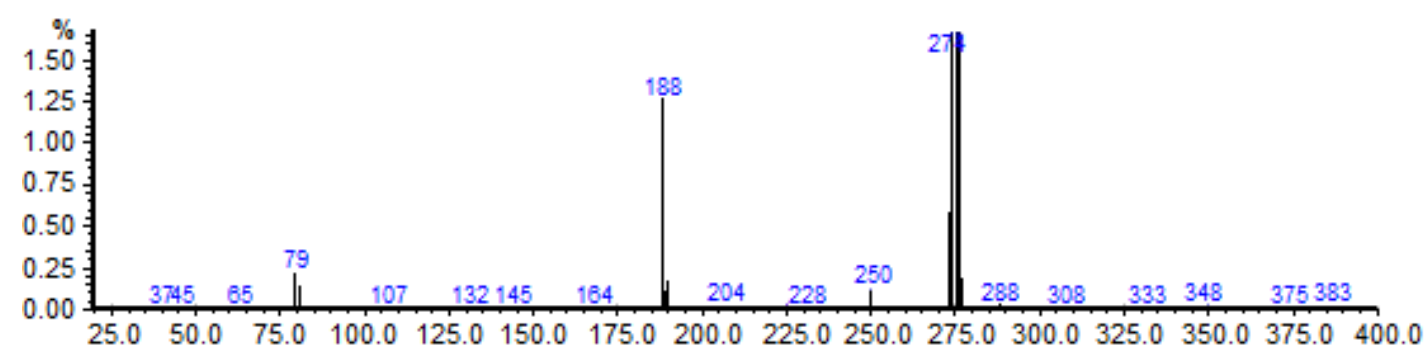

Fig 2. Mass of $\mathrm{L}^{1}$ 


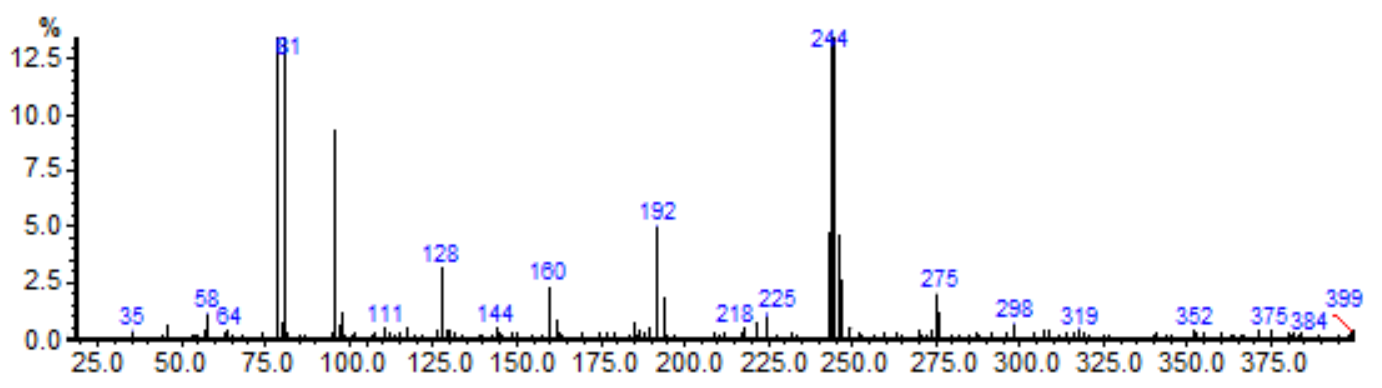

Fig 3. Mass of 3-(2-thiocyanatoacetyl)-2H-chromen-2-one $\mathrm{L}^{2}$

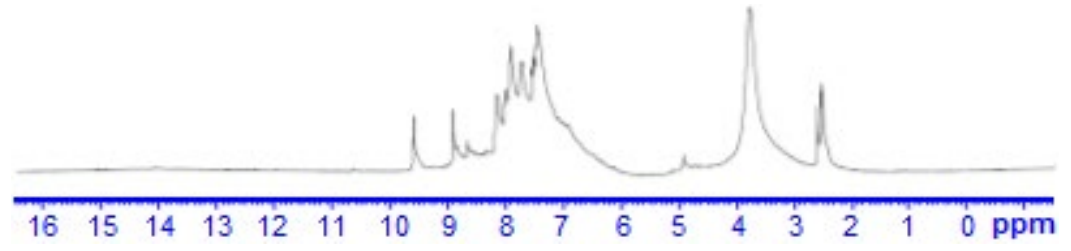

Fig 4. $\mathrm{H}$-NMR spectra of $\mathrm{L}^{1}$ in d6-DMSOsolvent

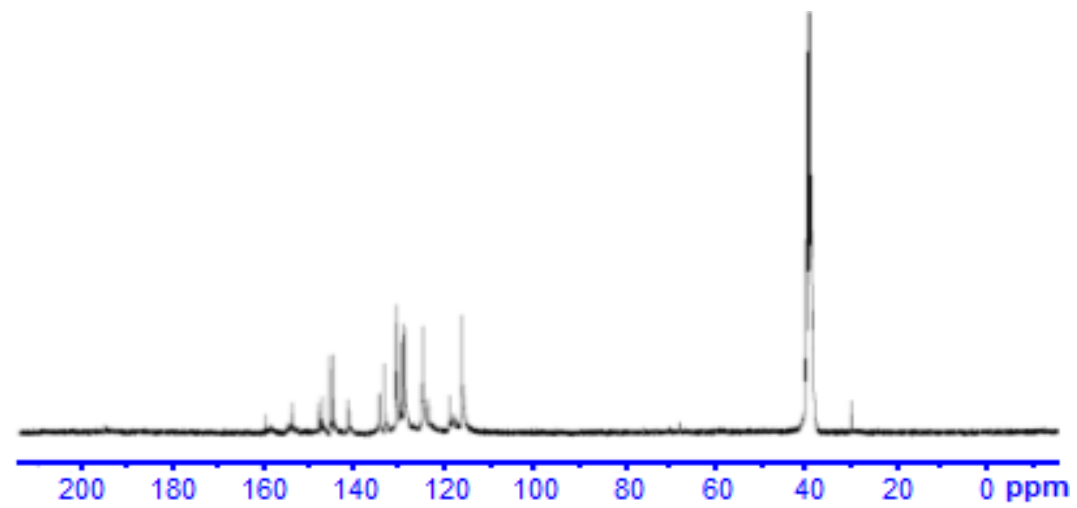

Fig 5. ${ }^{13} \mathrm{C}-\mathrm{NMR}$ spectra of $\mathrm{L}^{1}$ in $d 6$-DMSO solvent

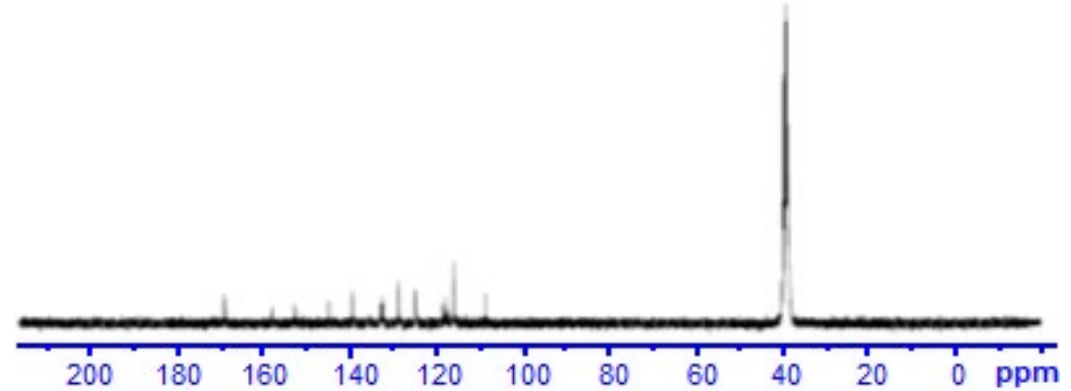

Fig 6. ${ }^{13} \mathrm{C}$-NMR spectra of $\mathrm{L}^{2}$ in $d 6$-DMSO solvent

of the phenyl and pyrazine moieties [18]. The singlet at $4.60 \mathrm{ppm}$ was attributed to the two protons of the $-\mathrm{CH}_{2}-$ $\mathrm{Br}$ group [10]. The signal of the $-\mathrm{NH}$ proton in the quinoxaline moiety was observed at $9.55 \mathrm{ppm}$, and the singlet peak at $8.77 \mathrm{ppm}$ is attributed to $\mathrm{H}-\mathrm{C}=\mathrm{C}$ - in position 4 of the coumarin ring. As well as the Fig. 5 shows the ${ }^{13} \mathrm{C}-\mathrm{NMR}$ of $\mathrm{L} 1$ in $\mathrm{d} 6-\mathrm{DMSO}$ which displays resonance peaks related to aromatic $-\mathrm{C}=\mathrm{C}-$ in the regions $(113-125)$ ppm and 127-131 ppm are assigned to $-\mathrm{C}=\mathrm{O},-\mathrm{C}=\mathrm{N}$ and $-\mathrm{C}-\mathrm{N}$ moieties respectively. The Fig. $5-6$ show the ${ }^{1} \mathrm{H}$ and ${ }^{13} \mathrm{C}-\mathrm{NMR}$ spectra of $\mathrm{L}^{2}$ in $\mathrm{d} 6-\mathrm{DMSO}$ where the absorptions in the region 6.2-7.80 $\mathrm{ppm}$ are ascribed to Ar-H protons and the chemical shift at (8.04-8.70) ppm are assigned to protons of the annulated coumarin ring [12-16]. The singlet peak at (11.40-11.50) ppm may be attributed to $\mathrm{H}-\mathrm{C}=\mathrm{C}$ of the coumarin ring in $\mathrm{C} 4$ 
position. However, the weak peak at $4.10 \mathrm{ppm}$ could be assigned to $\mathrm{CH}_{2}-\mathrm{Br}$ due to the effect of electronwithdrawing effect of bromine and thiocyanato groups on the deshielding of aliphatic protons toward the weak magnetic field [11,19].

\section{FT-IR Spectra}

The appearance of medium absorptions around (780-870) $\mathrm{cm}^{-1}$ in the IR-spectrum of $\omega$-bromo-3acetylcoumarin confirms the bromination on methyl group of the starting material [16-20]. As well as the strong absorptions in the IR spectrum of $\mathrm{L}^{1}$ around 2962, 1710, and $1630 \mathrm{~cm}^{-1}$ could be attributed to aliphatic $-\mathrm{CH}_{2}$, $-\mathrm{C}=\mathrm{O}$ of pyran ring and $-\mathrm{C}=\mathrm{C}-$ moiety respectively [12]. Furthermore, the IR spectrum of ligand $\mathrm{L}^{1}$ exhibited medium band at $1630 \mathrm{~cm}^{-1}$ assigned to $-\mathrm{C}=\mathrm{N}-$ of quinoxaline moiety then support the ring closure up on condensation with 1,2-phenylenediamine [13]. However, the $\mathrm{L}^{2}$ ligand displayed distinct bands around 1450-1590, 2230-2130 and $1735 \mathrm{~cm}^{-1}$ assigned to $-\mathrm{C}=\mathrm{N}-,-\mathrm{S}-\mathrm{C}=\mathrm{N}-$ and $-\mathrm{C}=\mathrm{O}$ respectively then confirms the proceeding the nucleophilic substitution of $-\mathrm{SCN}$ on the carbon atom bearing $-\mathrm{Br}$ moiety [11,17]. The comparison of the positions of these bands with those observed in the infrared spectra of its $\mathrm{Ni}(\mathrm{II}), \mathrm{Co}(\mathrm{II}), \mathrm{Cu}(\mathrm{II})$ and $\mathrm{Cd}(\mathrm{II})$ complexes indicated that the band at $1670-1705 \mathrm{~cm}^{-1}$ showed a marked shift, this discussed that carbonyl group shared in the chelation toward metal ions under study, whereas the broad bands around (3328-3306) $\mathrm{cm}^{-1}$ may be resulted from stretching vibration of coordinated water molecules in the structures of metal complexes [17]. This fact suggests the coordination of $\mathrm{L}^{2}$ through the nitrogen $-\mathrm{S}-\mathrm{CN}$ and oxygen of $-\mathrm{C}=\mathrm{O}$ together and tending to form stable complexes. The observed medium intensity band at $912 \mathrm{~cm}^{-1}$ in the free $\mathrm{L}^{2}$ ligand assigned to the rocking of $\delta(\mathrm{CSC})$ moiety with lowering in their energies in all IR spectra of metal complexes to a range $890-910 \mathrm{~cm}^{-1}$ confirming the participation of nitrogen atom in bonding with the empty orbitals of the metal ion $[1,12]$. On the other hand, the new absorptions in the regions 400-470 and $490-5440 \mathrm{~cm}^{-1}$ are ascribed to M-O and M-N bonds [21-22].

\section{Magnetic Measurements}

The magnetic susceptibilities of the complexes, recorded at room temperature show low magnetic moments indicating the presence of a spin-exchange interactions between the metal ions. The values obtained of copper(II) complexes lie in the 1.73-1.85 BM range and corresponds to one unpaired electron. As well as the orbital contributions of cobalt(II) and nickel(II) complexes in the ranges 4.8-4.9 and 2.88-3.22 BM respectively indicating the high spin octahedral structures around $\mathrm{Co}(\mathrm{II})$ and $\mathrm{Ni}(\mathrm{II})$ ions [23]. The expected enhancement in the values of magnetic moments for cobalt(II) complexes are reasoned from the orbital contribution in the $t_{2} g$ level [23] then supports the octahedral environment around the $\mathrm{Co}(\mathrm{II})$ ion, Table 1.

\section{Electronic Spectral Studies}

The ligands $\mathrm{L}^{1}$ and $\mathrm{L}^{2}$ exhibited similar spectral features in the UV-Vis region with bands around 255310 and $330-366 \mathrm{~nm}$, respectively. These absorptions are assigned to a ligand transition $\left(n-\pi^{*}\right)$ and $\left(\pi-\pi^{\star}\right)$. The green solutions of cobalt(II) complexes exhibited weak peaks around $600-800 \mathrm{~nm}$ and $677-800 \mathrm{~nm}$ assigning to spin-allowed transitions ${ }^{4} \mathrm{~T}_{1} \mathrm{~g} \rightarrow{ }^{4} \mathrm{~T}_{2} \mathrm{~g},{ }^{4} \mathrm{~T}_{1} \mathrm{~g} \rightarrow{ }^{4} \mathrm{~A}_{2} \mathrm{~g}$ respectively, then confirms the octahedral geometry of CoL complexes. As well as the nickel(II) complexes in DMF solutions displayed spin-allowed transitions at 488-722 nm and 477-766 nm respectively. Furthermore, the copper(II) complexes showed separated low-energy absorptions around 550-760 $\mathrm{nm}$ and 390-588 $\mathrm{nm}$ which attributed to ${ }^{2} \mathrm{~B}_{1} \mathrm{~g} \rightarrow{ }^{2} \mathrm{~B}_{2} \mathrm{~g}$ and ${ }^{2} \mathrm{~B}_{1} \mathrm{~g} \rightarrow{ }^{2} \mathrm{Eg}$ transitions revealing the formation of distorted octahedral around $\mathrm{Cu}$ (II) ion [22-23]. However, the cadmium(II) complexes formed with $\mathrm{L}^{1}$ showed only absorptions in the $250-350 \mathrm{~nm}$ indicating the charge transfer and the aromatic bands of the coumarin ring [23-25].

\section{Thermal Analysis}

The thermal degradation of $\mathrm{Co}(\mathrm{II}), \mathrm{Cu}(\mathrm{II})$ and Cd(II) complexes was studied using TG-DSC analysis, Table 2. The data from the thermogravimetric analysis clearly indicated that the decomposition of the complexes 
Table 1. The electronic spectra and molar conductance of the prepared complexes

\begin{tabular}{|c|c|c|c|c|c|}
\hline Compound & $\begin{array}{c}\text { UV-visible } \lambda \\
(\mathrm{nm})\end{array}$ & $\begin{array}{c}\text { Tentative } \\
\text { assignment }\end{array}$ & $\mu$ (B.M.) & Geometry & $\begin{array}{c}€ \\
\text { L.mole }{ }^{-1} \cdot \mathrm{cm}^{-1}\end{array}$ \\
\hline \multirow{2}{*}{$\mathrm{L}^{1}$} & 310 & $\mathrm{n} \rightarrow \pi^{\star}$ & \multirow{2}{*}{ - } & \multirow{2}{*}{ - } & 7400 \\
\hline & 255 & $\pi \rightarrow \pi^{\star}$ & & & 20000 \\
\hline \multirow{3}{*}[\mathrm{Co}(\mathrm{L}^{1})_{2}\mathrm{Cl}_{2}]{$\cdot 2 \mathrm{H}_{2} \mathrm{O}$} & 340 & LMCT & \multirow{3}{*}{4.80} & \multirow{3}{*}{ Octahedral } & 30000 \\
\hline & 600 & ${ }^{4} \mathrm{~T}_{1} \mathrm{~g} \rightarrow{ }^{4} \mathrm{~T}_{2} \mathrm{~g}(\mathrm{~F})$ & & & 1000 \\
\hline & 800 & ${ }^{4} \mathrm{~T}_{1} \mathrm{~g} \rightarrow{ }^{4} \mathrm{~A}_{2} \mathrm{~g}(\mathrm{~F})$ & & & 700 \\
\hline \multirow{3}{*}[\mathrm{Ni}(\mathrm{L}^{1})_{2}\mathrm{Cl}_{2}]{$\cdot \mathrm{H}_{2} \mathrm{O}$} & 300 & LMCT & \multirow{3}{*}{2.88} & \multirow{3}{*}{ Octahedral } & 18700 \\
\hline & 488 & ${ }^{3} \mathrm{~A}_{2} \mathrm{~g} \rightarrow{ }^{3} \mathrm{~T}_{2} \mathrm{~g}(\mathrm{~F})$ & & & 766 \\
\hline & 722 & ${ }^{3} \mathrm{~A}_{12} \mathrm{~g} \rightarrow{ }^{3} \mathrm{~T}_{1} \mathrm{~g}(\mathrm{~F})$ & & & 17900 \\
\hline \multirow{3}{*}[\mathrm{Cu}(\mathrm{L}^{1})_{2}\mathrm{Cl}_{2}]{} & 249 & LMCT & \multirow{3}{*}{1.73} & \multirow{3}{*}{ Octahedral } & 26100 \\
\hline & 550 & ${ }^{2} \mathrm{~A}_{1} \mathrm{~g} \rightarrow{ }^{2} \mathrm{~B}_{1} \mathrm{~g}$ & & & 650 \\
\hline & 760 & ${ }^{2} \mathrm{~A}_{1} \mathrm{~g} \rightarrow{ }^{2} \mathrm{~B}_{2} \mathrm{~g}$ & & & 1010 \\
\hline \multirow{3}{*}[\mathrm{Cd}(\mathrm{L}^{1})_{2}]{$\mathrm{Cl}_{2}$} & 319 & $\mathrm{n} \rightarrow \pi^{*}$ & \multirow{3}{*}{0.0} & \multirow{3}{*}{ Tetrahedral } & 9570 \\
\hline & 350 & LMCT & & & 13950 \\
\hline & 389 & & & & 24000 \\
\hline \multirow{2}{*}{$\mathrm{L}^{2}$} & 366 & $\mathrm{n} \rightarrow \pi^{*}$ & \multirow[b]{2}{*}{-} & & 10300 \\
\hline & 330 & LMCT & & & 21200 \\
\hline \multirow{3}{*}[\mathrm{Co}(\mathrm{L}^{2})_{2}\mathrm{Cl}_{2}]{$\cdot \mathrm{H}_{2} \mathrm{O}$} & 290 & $\pi \rightarrow \pi^{\star}$ & \multirow{3}{*}{4.90} & \multirow{3}{*}{ Octahedral } & 30000 \\
\hline & 677 & ${ }^{4} \mathrm{~T}_{1} \mathrm{~g} \rightarrow{ }^{4} \mathrm{~T}_{2} \mathrm{~g}(\mathrm{~F})$ & & & 1220 \\
\hline & 800 & ${ }^{4} \mathrm{~T}_{1} \mathrm{~g} \rightarrow{ }^{4} \mathrm{~A}_{2} \mathrm{~g}(\mathrm{~F})$ & & & 1010 \\
\hline \multirow{3}{*}[\mathrm{Ni}(\mathrm{L}^{2})_{2}\mathrm{Cl}_{2}]{} & 233 & $\pi \rightarrow \pi^{*}$ & \multirow{3}{*}{3.22} & \multirow{3}{*}{ Octahedral } & 27000 \\
\hline & 477 & ${ }^{3} \mathrm{~A}_{2} \mathrm{~g} \rightarrow{ }^{3} \mathrm{~T}_{2} \mathrm{~g}(\mathrm{~F})$ & & & 1033 \\
\hline & 766 & ${ }^{3} \mathrm{~A}_{12} \mathrm{~g} \rightarrow{ }^{3} \mathrm{~T}_{1} \mathrm{~g}(\mathrm{~F})$ & & & 944 \\
\hline \multirow{3}{*}[\mathrm{Cu}(\mathrm{L}^{2})_{2}\mathrm{Cl}_{2}]{$\cdot 2 \mathrm{H}_{2} \mathrm{O}$} & 306 & $\mathrm{n} \rightarrow \pi^{*}$ & \multirow{3}{*}{1.85} & \multirow{3}{*}{ Octahedral } & 15500 \\
\hline & 390 & LMCT & & & 31000 \\
\hline & 588 & ${ }^{2} \mathrm{Eg} \rightarrow{ }^{2} \mathrm{~T}_{2} \mathrm{~g}$ & & & 1300 \\
\hline \multirow{2}{*}[\mathrm{Cd}(\mathrm{L}^{2})2]{$\mathrm{Cl}_{2}$} & 290 & $\mathrm{n} \rightarrow \pi^{\star}$ & \multirow{2}{*}{0.00} & \multirow{2}{*}{ Tetrahedral } & 29400 \\
\hline & 377 & LMCT & & & 23899 \\
\hline
\end{tabular}

$€$ : molar extinction coefficients of the prepared compounds

Table 2. TG-DTA of $\mathrm{Co}(\mathrm{II}), \mathrm{Cu}(\mathrm{II})$ and $\mathrm{Cd}(\mathrm{II})$ complexes with the $\mathrm{L}^{1}$ ligand

\begin{tabular}{cclccc}
\hline Compound & $\begin{array}{c}\text { Decomposition } \\
\text { step }\end{array}$ & $\begin{array}{c}\text { Temperature } \\
\text { range }\left({ }^{\circ} \mathrm{C}\right)\end{array}$ & $\begin{array}{c}\text { Removes } \\
\text { species }\end{array}$ & $\begin{array}{c}\text { Weight loss } \\
\text { \% (Calc. })\end{array}$ & $\begin{array}{c}\text { Weight Loss } \\
\text { \% Found }\end{array}$ \\
\hline \multirow{2}{*}[\mathrm{Co}(\mathrm{L}^{1})_{2}\mathrm{Cl}_{2}]{$\cdot 2 \mathrm{H}_{2} \mathrm{O}$} & $1^{\text {st }}$ & $147-181$ & $2 \mathrm{H}_{2} \mathrm{O}$ & 2.64 & 2.04 \\
& $2^{\text {nd }}$ & $181-247$ & $\mathrm{Cl}$ & 5.4 & 4.4 \\
& $3^{\text {rd }}$ & $247-352$ & $\left(\mathrm{C}_{2} \mathrm{H}_{6} \mathrm{~N}_{2} \mathrm{Cl}\right)$ & 16.72 & 16.63 \\
\hline & $1^{\text {st }}$ & $45-63.63$ & $-2 \mathrm{Cl}$ & 3.3 & 3.16 \\
{$\left[\mathrm{Cu}\left(\mathrm{L}^{1}\right)_{2} \mathrm{Cl}_{2}\right]$} & $2^{\text {nd }}$ & $63-116.84$ & $-\mathrm{C}_{2} \mathrm{H}_{6} \mathrm{~N}_{2} \mathrm{Cl}$ & 7.2 & 6.95 \\
& $3^{\text {rd }}$ & $116-261$ & $-\mathrm{C}_{8} \mathrm{H}_{10}$ & 14.04 & 13.75 \\
& $4^{\text {th }}$ & $261.8-368$ & $-\mathrm{C}_{4} \mathrm{H}_{2} \mathrm{O}_{2}$ & 19.27 & 18.58 \\
\hline & $1^{\text {st }}$ & $45-119$ & $2 \mathrm{Cl}_{2}$ & 2.44 & 2.37 \\
$\mathrm{Cd}\left[\mathrm{L}^{1}\right] \mathrm{Cl}_{2}$ & $2^{\text {nd }}$ & $119-222$ & $-\mathrm{C}_{2} \mathrm{H}_{3} \mathrm{~N}$ & 10.7 & 11.9 \\
& $3^{\text {rd }}$ & $222-351$ & $-\mathrm{C}_{2} \mathrm{H}_{2} \mathrm{~N}$ & 18.57 & 17.1 \\
& & & $\mathrm{C}_{2} \mathrm{H}_{6} \mathrm{~N}_{2}$ & & \\
\hline
\end{tabular}


proceeds in three or four steps. The hydrated water molecules were lost between $50-63.63^{\circ} \mathrm{C}$ in all complexes, Fig. 8-11. The $\mathrm{CuL}^{1}$ complex with $\mathrm{L}^{1}$ ligand showed exothermic peaks over temperatures $\left(122^{\circ} \mathrm{C}\right)$ as indicated

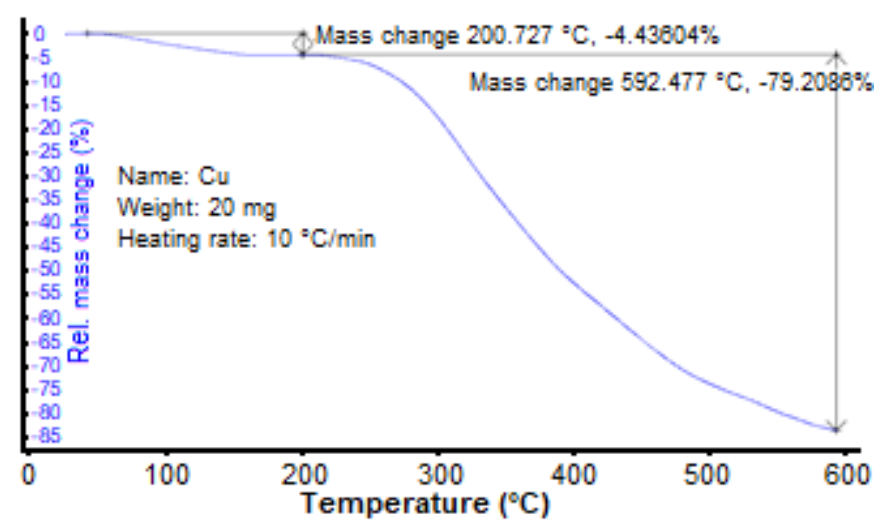

Fig 7. TG analysis of $\mathrm{Cu}(\mathrm{II})$ complex with $\mathrm{L}^{1}$ ligand by DSC analysis. The corresponding values of the entropy of activation $\triangle S^{*}$, wherein range -0.547 to $-0.480 \mathrm{~J} \mathrm{~mole}^{-1}$. The negative values of $\Delta \mathrm{H}^{\star}$ means that the decomposition processes are endothermic, Fig. 7-8.

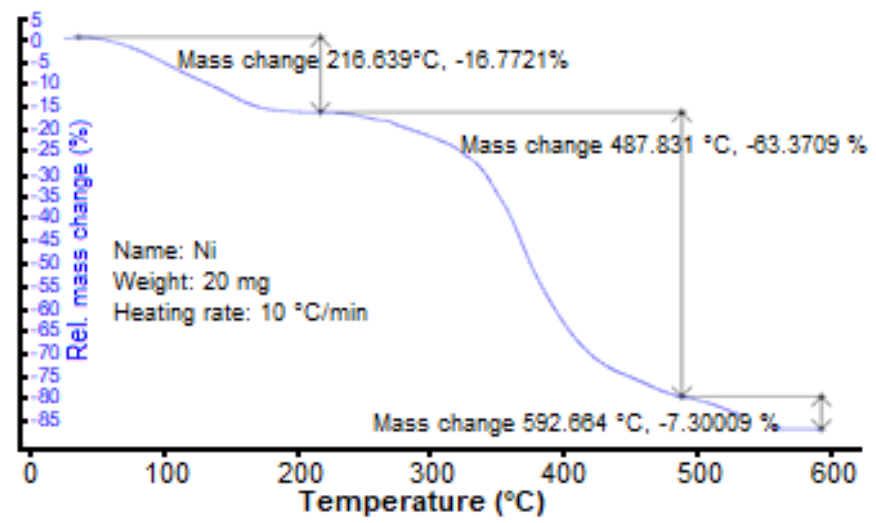

Fig 8. TG analysis of $\left[\mathrm{Ni}\left(\mathrm{L}^{1}\right)_{2} \mathrm{Cl}_{2}\right]$ complex
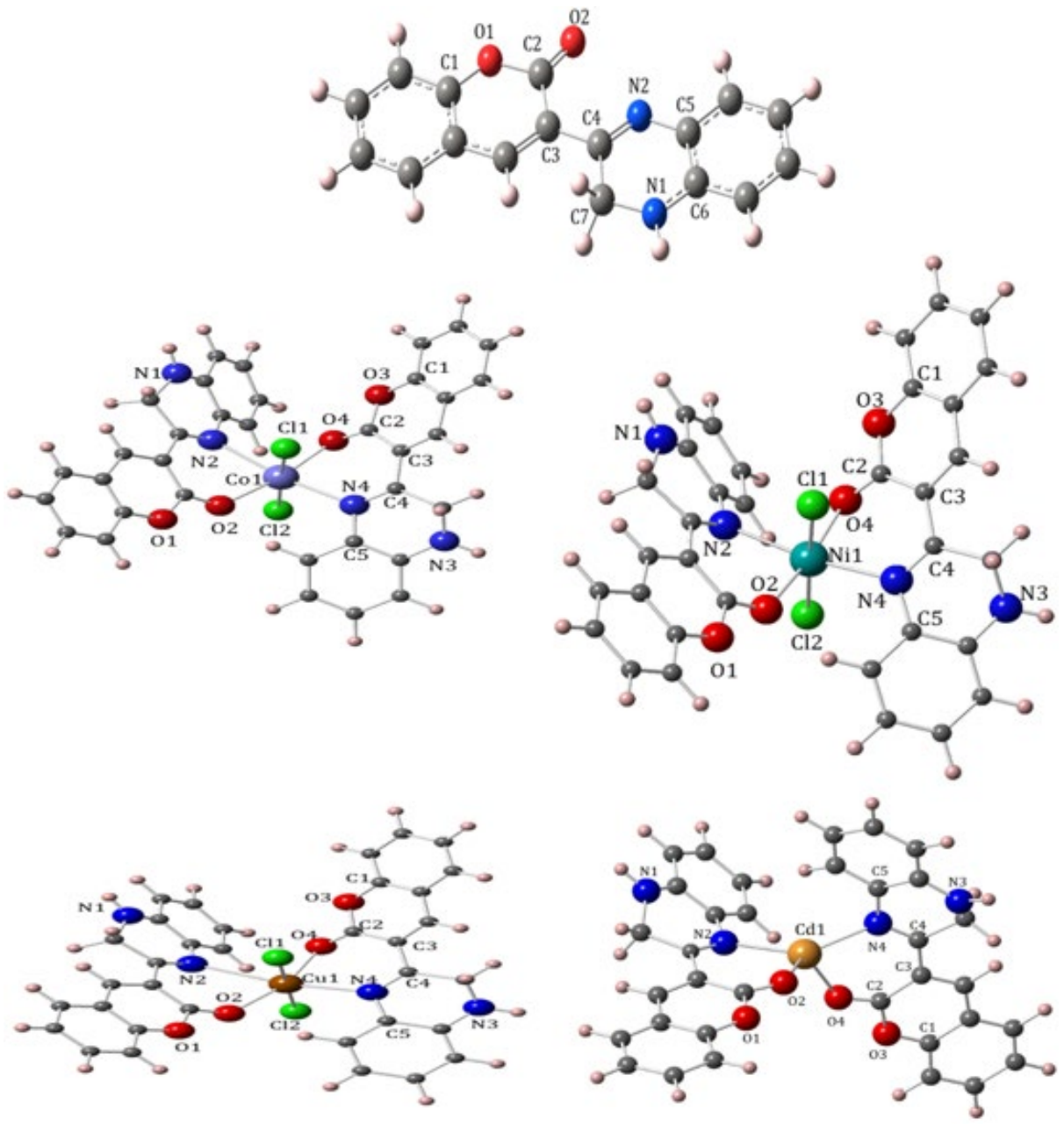

Fig 9. The optimized structures of $L^{1}$ series 


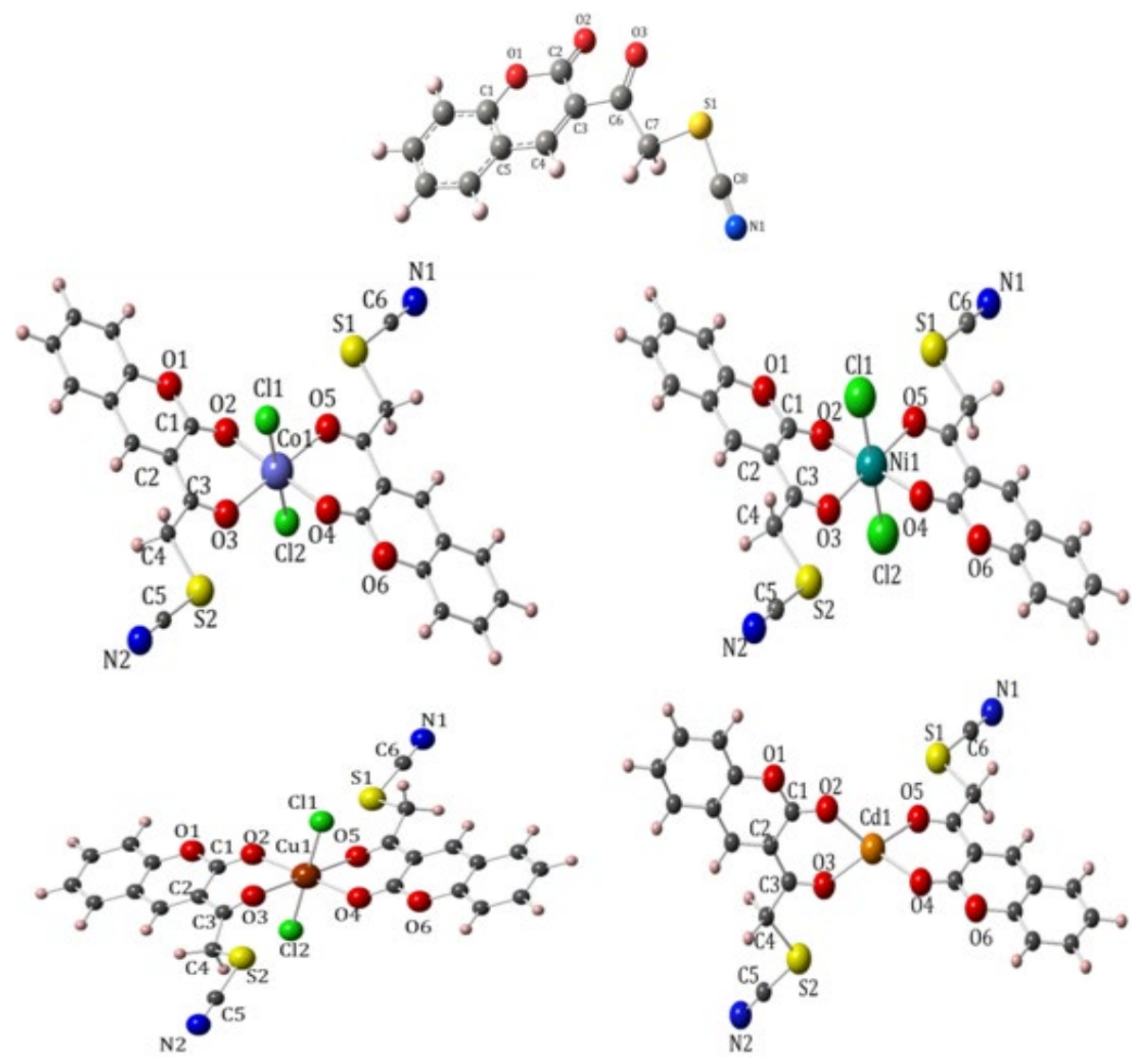

Fig 10. The optimized structures of $\mathrm{L}^{2}$ series
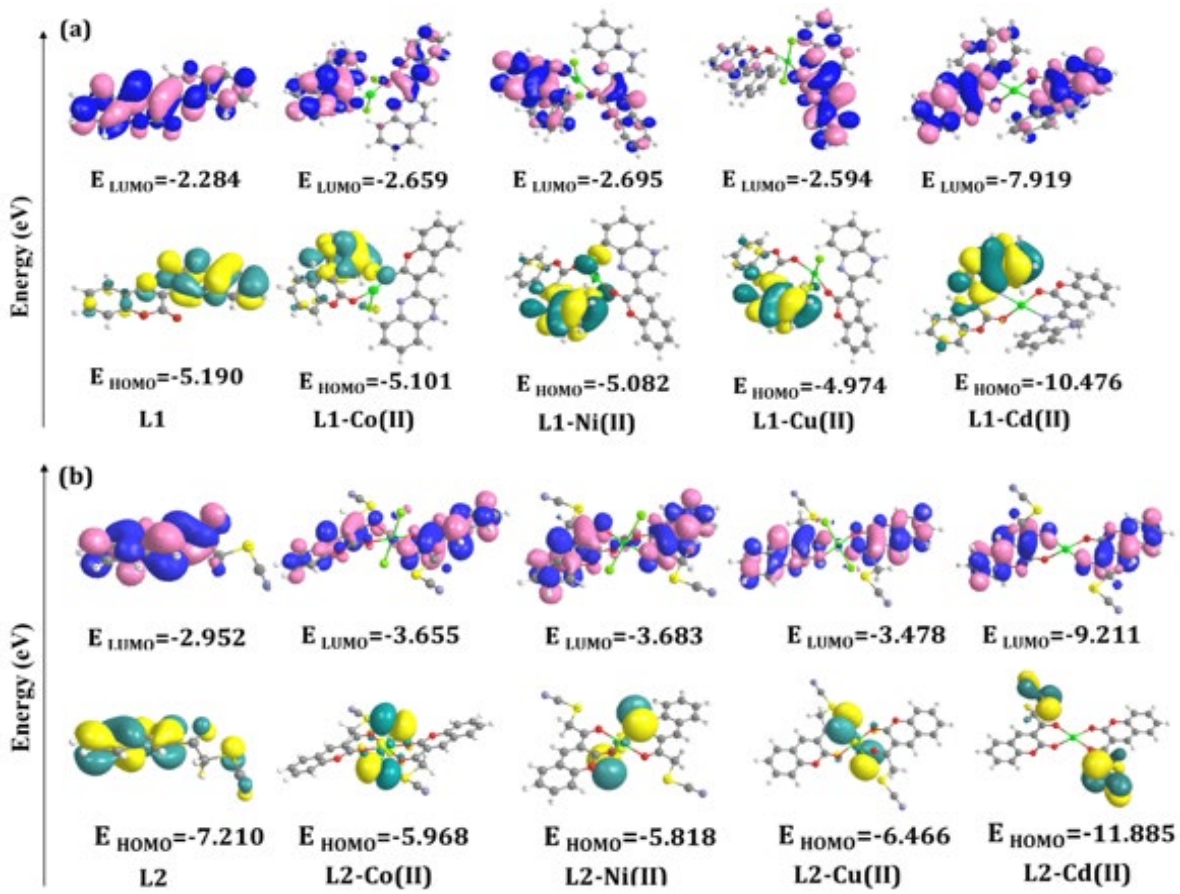

Fig 11. Surface plot of the frontier orbitals (a MOs) of the optimized Schiff base (a) $\mathrm{L}^{1}$ and (b) $\mathrm{L}^{2}$ and the related metal complexes along with their energies. The yellow and pink colors exhibit a positive charge and the green and blue colors show the negative charge 


\section{Theoretical Studies}

\section{Structural optimization}

To establish the electronic structures of the $\mathrm{L}^{1}$ and $\mathrm{L}^{2}$ Schiff base ligands and the corresponding metal complexes with $\mathrm{Co}(\mathrm{II}), \mathrm{Ni}(\mathrm{II}), \mathrm{Cu}(\mathrm{II})$ and $\mathrm{Cd}(\mathrm{II})$ ions DFT computations were employed in the ground state. The geometric structures of the isolated ligands $\left(\mathrm{L}^{1}\right.$ and $\left.L^{2}\right)$ together with their complexes were fully optimized using B3LYP functional. Due to the conjoint of the electronic spectra and magnetic susceptibility measurements, a plausible octahedral geometries suggested for the cobalt(II), Nickel(II) and copper(II) complexes while the cadmium(II) complexes adopt a tetrahedral geometry. The optimized structures of the titled compounds of $\mathrm{L}^{1}$ and $\mathrm{L}^{2}$ series were depicted in Fig. 11 and 12, respectively. The optimized geometric parameters are given in Table 3. Both $\mathrm{L}^{1}$ and $\mathrm{L}^{2}$ ligands behave as a bidentate ligand so far the coordination in $\mathrm{L}^{1}$ is achieved through the phenoxo $\mathrm{O}(2)$, the imine $\mathrm{N}(2)$, while in $\mathrm{L}^{2}$ is occurred via both phenoxo $\mathrm{O}(2)$ and $\mathrm{O}(3)$ atoms. So, the best possible structures of $\mathrm{Co}(\mathrm{II}), \mathrm{Ni}(\mathrm{II})$, $\mathrm{Cu}$ (II) complexes of both Schiff bases have resulted in a distorted octahedral coordination sphere in which two chlorine atoms were coordinated in the axial position of the complexes. On the other hand, the cadmium(II) complexes have a different geometry than the other metal ions with a tetrahedral geometry, coordinating the phenoxo $\mathrm{O}(2)$ and $\mathrm{O}(4)$ and the imine $\mathrm{N}(2)$ and $\mathrm{N}(4)$ atoms relevant to $\mathrm{L}^{1}$ and also phenoxo $\mathrm{O}(2,4)$ and carbonyl $\mathrm{O}(3,5)$ atoms in $\mathrm{L}^{2}$ analogue, Fig. 9-10.

\section{TD-DFT calculations}

In order to get deep insights into the electronic transitions and the compositions of the molecular orbitals (MOs), TD-DFT calculations on the optimized geometries were employed by the PCM method, taken in DMSO solution [15]. A contour plot of selected molecular orbital with its density value $0.02 \mathrm{e} \mathrm{Bohr}^{-3}$ are given in Fig. 11. TD-DFT results showed that upon coordination of both Schiff base ligands to metal ions the energy differences of the frontier molecular orbital HOMOLUMO considerably decrease so that energy gap in $\mathrm{Cu}$ (II) complex of both $\mathrm{L}^{1}$ and $\mathrm{L}^{2}$ ligands is lower than those for other compounds. The analysis of the MO compositions revealed that the contributions of metal ions in the higher HOMO levels and lower LUMO levels in $\mathrm{L}^{1}$ complexes are very negligible, while these contributions are increased in lower HOMO levels (H-4, 14\% Co, 13\% $\mathrm{Ni}, 5 \% \mathrm{Cu}$ and $\mathrm{H}-103 \% \mathrm{Cd})$. Also, the compositions in the higher LUMO levels were obtained $(\mathrm{L}+12,75 \% \mathrm{Co}$, $75 \% \mathrm{Ni}, 72 \% \mathrm{Cu}$ and $\mathrm{L}+14,50 \% \mathrm{Cd}$ ) along with reduced contribution ( $18 \%)$ of $\pi$ ligand $\mathrm{L}^{1}$. In addition, in $\mathrm{L}^{2}$ complexes the major contributions for $\mathrm{L}+14$ are $(62 \%$ Co, $59 \% \mathrm{Ni}, 62 \% \mathrm{Cu}$ and $45 \% \mathrm{Cd}$ ) and those for $\mathrm{H}-11$ are taken $(23 \% \mathrm{Co}, 19 \% \mathrm{Ni}, 19 \% \mathrm{Cu}$ and $3 \% \mathrm{Cd})$ along with reduced contribution of the $\mathrm{L}^{2}$ ligand fragment about $80 \%$ for lower HOMO levels and $36 \%$ for the lower LUMO levels. From theoretical findings, it is clear that the most electron density is localized over the almost whole Schiff base and chlorine ligands and metal ions have insignificant participated in major HOMO and LUMO orbital.

The electronic transitions of the titled compounds are carried out using TDDFT/CPCM calculations in DMSO solvent in order to find out more details of the absorption bands about the compounds of this study. The results of TDDFT computations together with the experimental measurements of the metal complexes of both $\mathrm{L}^{1}$ and $\mathrm{L}^{2}$ ligand are tabulated in Table 4 and Table 5 , respectively. The calculated singlet-singlet transitions obtained from TDDFT are a reasonable agreement with the experimental ones. Fig. 12 and 13 show the TD-DFT spectra and molecular orbital diagram together with major electronic excited states of the compounds, respectively. The results reveal that the experimental peaks at around $800 \mathrm{~nm}$ for $\mathrm{CoL}^{1}$ and $\mathrm{CoL}^{2}$ (assigned to $\left.{ }^{4} \mathrm{~T}_{1} \mathrm{~g} \rightarrow{ }^{4} \mathrm{~A}_{2} \mathrm{~g}(\mathrm{~F})\right)$ are not resolved theoretically. A similar observation has been encountered in case of complex $\mathrm{NiL}^{2}$ where the experimental peak at $766 \mathrm{~nm}$ (assigned to $\left.{ }^{3} \mathrm{~A}_{2} \mathrm{~g} \rightarrow{ }^{3} \mathrm{~T}_{1} \mathrm{~g}(\mathrm{~F})\right)$ are not observed in theoretical one which those may be attributed to asymmetry forbidden transition in TD-DFT computations [26]. However, there may be an experimental peak due to vibronic couplings in this case.

The other low energy peak at $568.9 \mathrm{~nm}$ of complex $\mathrm{CdL}^{1}$ cannot be identified from its experimental spectra. 
Table 3. The electronic transition calculated by TDDFT/CPCM method of $\mathrm{L}^{1}$ and its metal complexes

\begin{tabular}{|c|c|c|c|c|c|c|c|c|c|}
\hline & \multicolumn{2}{|c|}{ Bond length $(\AA)$} & \multicolumn{3}{|l|}{ Bond angle $\left({ }^{\circ}\right)$} & \multicolumn{2}{|c|}{ Bond length $(\AA)$} & \multicolumn{2}{|c|}{ Bond angle $\left({ }^{\circ}\right)$} \\
\hline \multirow{8}{*}{$\mathbf{L}^{1}$} & $\mathrm{C}(1)-\mathrm{O}(1)$ & 1.36 & $\mathrm{O}(3)-\mathrm{C}(2)-\mathrm{O}(4)$ & 115.1 & \multirow{8}{*}{$\mathbf{L}^{2}$} & $\mathrm{C}(1)-\mathrm{O}(1)$ & 1.36 & $C(7)-S(1)$ & 1.848 \\
\hline & $\mathrm{C}(2)-\mathrm{O}(1)$ & 1.41 & $\mathrm{C}(4)-\mathrm{N}(4)-\mathrm{C}(5)$ & 121 & & $\mathrm{C}(2)-\mathrm{O}(1)$ & 1.4 & $C(8)-S(1)$ & 1.705 \\
\hline & $\mathrm{C}(2)-\mathrm{O}(2)$ & 1.2 & & & & $\mathrm{C}(2)-\mathrm{O}(2)$ & 1.2 & $\mathrm{C}(8)-\mathrm{N}(1)$ & 1.167 \\
\hline & $\mathrm{C}(6)-\mathrm{N}(1)$ & 1.37 & & & & $\mathrm{C}(6)-\mathrm{N}(1)$ & 1.37 & $S(1)-C(8)-N(1)$ & 177.9 \\
\hline & $\mathrm{C}(7)-\mathrm{N}(1)$ & 1.45 & & & & $C(2)-C(3)$ & 1.48 & $C(7)-S(1)-C(8)$ & 96.81 \\
\hline & $\mathrm{C}(4)-\mathrm{N}(2)$ & 1.29 & & & & $\mathrm{C}(3)-\mathrm{C}(4)$ & 1.36 & $C(6)-C(7)-S(1)$ & 108 \\
\hline & $\mathrm{C}(5)-\mathrm{N}(2)$ & 1.39 & & & & $\mathrm{C}(4)-\mathrm{C} 5)$ & 1.44 & $\mathrm{O}(1)-\mathrm{C}(2)-\mathrm{O}(2)$ & 117.6 \\
\hline & $\mathrm{C}(2)-\mathrm{C}(3)$ & 1.49 & & & & $\mathrm{C}(1)-\mathrm{C}(5)$ & 1.41 & $\mathrm{O}(3)-\mathrm{C}(2)-\mathrm{C}(3)$ & 122.2 \\
\hline \multirow{11}{*}{$\mathrm{CoL}^{1}$} & $\mathrm{Co}(1)-\mathrm{Cl}(1)$ & 2.52 & $\mathrm{~N}(2)-\mathrm{Co}(1)-\mathrm{N}(4)$ & 168.8 & \multirow{11}{*}{$\mathrm{CoL}^{2}$} & $\mathrm{Co}(1)-\mathrm{Cl}(1)$ & 2.41 & $C(5)-S(2)$ & 1.76 \\
\hline & $\mathrm{Co}(1)-\mathrm{Cl}(2)$ & 2.4 & $\mathrm{O}(2)-\mathrm{Co}(1)-\mathrm{O}(4)$ & 169.2 & & $\mathrm{Co}(1)-\mathrm{Cl}(2)$ & 2.41 & $\mathrm{C}(5)-\mathrm{N}(2)$ & 1.769 \\
\hline & $\mathrm{Co}(1)-\mathrm{O}(2)$ & 2.11 & $\mathrm{Cl}(1)-\mathrm{Co}(1)-\mathrm{Cl}(2)$ & 173.9 & & $\mathrm{Co}(1)-\mathrm{O}(2)$ & 2.15 & $\mathrm{Cl}(1)-\mathrm{Co}(1)-\mathrm{O}(5)$ & 94.2 \\
\hline & $\mathrm{Co}(1)-\mathrm{O}(4)$ & 2.12 & $\mathrm{O}(3)-\mathrm{C}(2)-\mathrm{O}(4)$ & 115.3 & & $\mathrm{Co}(1)-\mathrm{O}(4)$ & 2.15 & $\mathrm{Cl}(1)-\mathrm{Co}(1)-\mathrm{O}(2)$ & 87.01 \\
\hline & $\mathrm{Co}(1)-\mathrm{N}(2)$ & 2.32 & $\mathrm{C}(4)-\mathrm{N}(4)-\mathrm{C}(5)$ & 119.5 & & $\mathrm{Co}(1)-\mathrm{O}(3)$ & 2.16 & $\mathrm{Cl}(2)-\mathrm{Co}(1)-\mathrm{O}(3)$ & 94.23 \\
\hline & $\mathrm{Co}(1)-\mathrm{N}(4)$ & 2.36 & & & & $\mathrm{Co}(1)-\mathrm{O}(5)$ & 2.16 & $\mathrm{Cl}(2)-\mathrm{Co}(1)-\mathrm{O}(4)$ & 87.02 \\
\hline & $\mathrm{C}(1)-\mathrm{O}(3)$ & 1.24 & & & & $\mathrm{C}(1)-\mathrm{O}(1)$ & 1.4 & $\mathrm{O}(2)-\mathrm{Co}(1)-\mathrm{O}(3)$ & 80.14 \\
\hline & $\mathrm{C}(2)-\mathrm{O}(4)$ & 1.39 & & & & $\mathrm{C}(2)-\mathrm{O}(2)$ & 1.23 & $\mathrm{O}(5)-\mathrm{Co}(1)-\mathrm{O}(4)$ & 80.14 \\
\hline & $\mathrm{C}(2)-\mathrm{C}(3)$ & 1.46 & & & & $C(2)-C(3)$ & 1.48 & $C(4)-S(2)-C(5)$ & 95.43 \\
\hline & $\mathrm{C}(4)-\mathrm{N}(2)$ & 1.31 & & & & $\mathrm{C}(3)-\mathrm{O}(3)$ & 1.25 & $S(2)-C(5)-N(2)$ & 178.3 \\
\hline & $\mathrm{C}(5)-\mathrm{N}(2)$ & 1.42 & & & & $C(4)-S(2)$ & 1.91 & & \\
\hline \multirow{11}{*}{$\mathrm{NiL}^{1}$} & $\mathrm{Ni}(1)-\mathrm{Cl}(1)$ & 2.53 & $\mathrm{~N}(2)-\mathrm{Ni}(1)-\mathrm{N}(4)$ & 170.6 & \multirow{11}{*}{$\mathrm{NiL}^{2}$} & $\mathrm{Ni}(1)-\mathrm{Cl}(1)$ & 2.43 & $C(5)-S(2)$ & 1.76 \\
\hline & $\mathrm{Ni}(1)-\mathrm{Cl}(2)$ & 2.41 & $\mathrm{O}(2)-\mathrm{Ni}(1)-\mathrm{O}(4)$ & 171.5 & & $\mathrm{Ni}(1)-\mathrm{Cl}(2)$ & 2.43 & $\mathrm{C}(5)-\mathrm{N}(2)$ & 1.177 \\
\hline & $\mathrm{Ni}(1)-\mathrm{O}(2)$ & 2.06 & $\mathrm{Cl}(1)-\mathrm{Ni}(1)-\mathrm{Cl}(2)$ & 176.2 & & $\mathrm{Ni}(1)-\mathrm{O}(2)$ & 2.09 & $\mathrm{Cl}(1)-\mathrm{Ni}(1)-\mathrm{O}(5)$ & 94.16 \\
\hline & $\mathrm{Ni}(1)-\mathrm{O}(4)$ & 2.07 & $\mathrm{O}(3)-\mathrm{C}(2)-\mathrm{O}(4)$ & 115.4 & & $\mathrm{Ni}(1)-\mathrm{O}(4)$ & 2.09 & $\mathrm{Cl}(1)-\mathrm{Ni}(1)-\mathrm{O}(2)$ & 86.9 \\
\hline & $\mathrm{Ni}(1)-\mathrm{N}(2)$ & 2.28 & $\mathrm{C}(4)-\mathrm{N}(4)-\mathrm{C}(5)$ & 119.4 & & $\mathrm{Ni}(1)-\mathrm{O}(3)$ & 2.09 & $\mathrm{Cl}(2)-\mathrm{Ni}(1)-\mathrm{O}(3)$ & 86.89 \\
\hline & $\mathrm{Ni}(1)-\mathrm{N}(4)$ & 2.26 & & & & $\mathrm{Ni}(1)-\mathrm{O}(5)$ & 2.09 & $\mathrm{Cl}(2)-\mathrm{Ni}(1)-\mathrm{O}(4)$ & 94.15 \\
\hline & $\mathrm{C}(2)-\mathrm{O}(3)$ & 1.39 & & & & $\mathrm{C}(1)-\mathrm{O}(1)$ & 1.4 & $\mathrm{O}(2)-\mathrm{Ni}(1)-\mathrm{O}(3)$ & 83.82 \\
\hline & $\mathrm{C}(2)-\mathrm{O}(4)$ & 1.24 & & & & $\mathrm{C}(2)-\mathrm{O}(2)$ & 1.24 & $\mathrm{O}(5)-\mathrm{Ni}(1)-\mathrm{O}(4)$ & 83.81 \\
\hline & $C(2)-C(3)$ & 1.46 & & & & $C(2)-C(3)$ & 1.25 & $C(4)-S(2)-C(5)$ & 95.97 \\
\hline & $\mathrm{C}(4)-\mathrm{N}(4)$ & 1.31 & & & & $\mathrm{C}(3)-\mathrm{O}(3)$ & 1.48 & $S(2)-C(5)-N(2)$ & 178.4 \\
\hline & $\mathrm{C}(5)-\mathrm{N}(4)$ & 1.42 & & & & $C(4)-S(2)$ & 1.91 & & \\
\hline \multirow{11}{*}{$\mathrm{CuL}^{1}$} & $\mathrm{Cu}(1)-\mathrm{Cl}(1)$ & 2.41 & $\mathrm{~N}(2)-\mathrm{Cu}(1)-\mathrm{N}(4)$ & 168.6 & \multirow{11}{*}{$\mathrm{CuL}^{2}$} & $\mathrm{Cu}(1)-\mathrm{Cl}(1)$ & 2.37 & $C(5)-S(2)$ & 1.76 \\
\hline & $\mathrm{Cu}(1)-\mathrm{Cl}(2)$ & 2.35 & $\mathrm{O}(2)-\mathrm{Cu}(1)-\mathrm{O}(4)$ & 161.9 & & $\mathrm{Cu}(1)-\mathrm{Cl}(2)$ & 2.37 & $\mathrm{C}(5)-\mathrm{N}(2)$ & 1.177 \\
\hline & $\mathrm{Cu}(1)-\mathrm{O}(2)$ & 2.14 & $\begin{array}{l}\mathrm{Cl}(1)-\mathrm{Cu}(1)- \\
\mathrm{Cl}(2)\end{array}$ & 177.4 & & $\mathrm{Cu}(1)-\mathrm{O}(2)$ & 2.05 & $\mathrm{Cl}(1)-\mathrm{Cu}(1)-\mathrm{O}(5)$ & 95.74 \\
\hline & $\mathrm{Cu}(1)-\mathrm{O}(4)$ & 2.18 & $\mathrm{O}(3)-\mathrm{C}(2)-\mathrm{O}(4)$ & 115.5 & & $\mathrm{Cu}(1)-\mathrm{O}(4)$ & 2.05 & $\mathrm{Cl}(1)-\mathrm{Cu}(1)-\mathrm{O}(2)$ & 88.38 \\
\hline & $\mathrm{Cu}(1)-\mathrm{N}(2)$ & 2.59 & $\mathrm{C}(4)-\mathrm{N}(4)-\mathrm{C}(5)$ & 120.2 & & $\mathrm{Cu}(1)-\mathrm{O}(3)$ & 2.42 & $\mathrm{Cl}(2)-\mathrm{Cu}(1)-\mathrm{O}(3)$ & 88.4 \\
\hline & $\mathrm{Cu}(1)-\mathrm{N}(4)$ & 2.27 & & & & $\mathrm{Cu}(1)-\mathrm{O}(5)$ & 2.42 & $\mathrm{Cl}(2)-\mathrm{Cu}(1)-\mathrm{O}(4)$ & 95.74 \\
\hline & $\mathrm{C}(2)-\mathrm{O}(3)$ & 1.4 & & & & $\mathrm{C}(1)-\mathrm{O}(1)$ & 1.4 & $\mathrm{O}(2)-\mathrm{Cu}(1)-\mathrm{O}(3)$ & 77.12 \\
\hline & $\mathrm{C}(2)-\mathrm{O}(4)$ & 1.24 & & & & $\mathrm{C}(2)-\mathrm{O}(2)$ & 1.24 & $\mathrm{O}(5)-\mathrm{Cu}(1)-\mathrm{O}(4)$ & 77.12 \\
\hline & $C(2)-C(3)$ & 1.47 & & & & $C(2)-C(3)$ & 1.24 & $C(4)-S(2)-C(5)$ & 95.37 \\
\hline & $\mathrm{C}(4)-\mathrm{N}(4)$ & 1.31 & & & & $\mathrm{C}(3)-\mathrm{O}(3)$ & 1.49 & $S(2)-C(5)-N(2)$ & 178.2 \\
\hline & $\mathrm{C}(5)-\mathrm{N}(4)$ & 1.42 & & & & $C(4)-S(2)$ & 1.91 & & \\
\hline \multirow{9}{*}{$\mathrm{CdL}^{1}$} & $\mathrm{Cd}(1)-\mathrm{O}(2)$ & 2.18 & $\mathrm{~N}(2)-\mathrm{Cd}(1)-\mathrm{N}(4)$ & 145.2 & \multirow{9}{*}{$\mathrm{CdL}^{2}$} & $\mathrm{Cd}(1)-\mathrm{O}(2)$ & 2.17 & $\mathrm{O}(2)-\mathrm{Cd}(1)-\mathrm{O}(5)$ & 126.6 \\
\hline & $\mathrm{Cd}(1)-\mathrm{O}(4)$ & 2.18 & $\mathrm{O}(2)-\mathrm{Cd}(1)-\mathrm{O}(4)$ & 113.9 & & $\mathrm{Cd}(1)-\mathrm{O}(3)$ & 2.21 & $\mathrm{O}(3)-\mathrm{Cd}(1)-\mathrm{O}(4)$ & 126.7 \\
\hline & $\mathrm{Cd}(1)-\mathrm{N}(2)$ & 2.29 & $\mathrm{O}(3)-\mathrm{C}(2)-\mathrm{O}(4)$ & 113.9 & & $\mathrm{Cd}(1)-\mathrm{O}(4)$ & 2.17 & $\mathrm{O}(2)-\mathrm{Cd}(1)-\mathrm{O}(3)$ & 78.27 \\
\hline & $\mathrm{Cd}(1)-\mathrm{N}(4)$ & 2.29 & $\mathrm{C}(4)-\mathrm{N}(4)-\mathrm{C}(5)$ & 121.2 & & $\mathrm{Cd}(1)-\mathrm{O}(5)$ & 2.21 & $C(4)-S(2)-C(5)$ & 95.66 \\
\hline & $\mathrm{C}(2)-\mathrm{O}(3)$ & 1.37 & & & & $\mathrm{C}(1)-\mathrm{O}(1)$ & 1.37 & $S(2)-C(5)-N(2)$ & 178.9 \\
\hline & $\mathrm{C}(2)-\mathrm{O}(4)$ & 1.26 & & & & $\mathrm{C}(1)-\mathrm{O}(2)$ & 1.26 & & \\
\hline & $C(2)-C(3)$ & 1.46 & & & & $C(2)-C(3)$ & 1.46 & & \\
\hline & $\mathrm{C}(4)-\mathrm{N}(4)$ & 1.32 & & & & $C(3)-C(4)$ & 1.51 & & \\
\hline & $\mathrm{C}(5)-\mathrm{N}(4)$ & 1.42 & & & & $C(4)-S(2)$ & 1.91 & & \\
\hline
\end{tabular}


Table 4. The electronic transition calculated by TDDFT/CPCM method of $\mathrm{L}^{1}$ and its metal complexes

\begin{tabular}{|c|c|c|c|c|c|c|}
\hline Compound & $\begin{array}{c}\text { Excited } \\
\text { state }\end{array}$ & $\lambda_{\text {cal }}(\mathrm{nm}),(\mathrm{eV})$ & $\begin{array}{l}\text { Oscillator } \\
\text { strength (f) }\end{array}$ & Key transition & $\begin{array}{c}\lambda_{\exp }(\mathrm{nm}) \\
\varepsilon \mathrm{L} \cdot \mathrm{mole}^{-1} \cdot \mathrm{cm}^{-1}\end{array}$ & Character \\
\hline \multirow{3}{*}{$\mathrm{L}^{1}$} & S3 & $359.4,3.4496$ & 0.7037 & H-2 $\rightarrow$ LUMO (\%68) & $310(7400)$ & $\mathrm{n} \rightarrow \pi^{*}$ \\
\hline & S6 & $292.1,4.2436$ & 0.1663 & H-4 $\rightarrow$ LUMO (\%64) & $255(20000)$ & $\pi \rightarrow \pi^{*}$ \\
\hline & S12 & $255.7,4.8488$ & 0.1938 & $\mathrm{H}-1 \rightarrow \mathrm{L}+1(\% 57)$ & & \\
\hline \multirow{5}{*}{$\mathrm{CoL}^{1}$} & S8 & $594.28,2.0863$ & 0.1187 & $\operatorname{HOMO}(\beta) \rightarrow \operatorname{LUMO}(\beta)(\% 69)$ & $340(30000)$ & LMCT \\
\hline & S9 & $576.4,2.1508$ & 0.1026 & $\mathrm{H}-1(\beta) \rightarrow \mathrm{L}+1(\beta)(\% 60)$ & $600(1000)$ & ${ }^{4} \mathrm{~T}_{1} \mathrm{~g} \rightarrow{ }^{4} \mathrm{~T}_{2} \mathrm{~g}(\mathrm{~F})$ \\
\hline & S21 & $415.0,2.9875$ & 0.0921 & H-2 (a) $\rightarrow$ LUMO $(\alpha)(\% 67)$ & $800(700)$ & ${ }^{4} \mathrm{~T}_{1} \mathrm{~g} \rightarrow{ }^{4} \mathrm{~A}_{2} \mathrm{~g}(\mathrm{~F})$ \\
\hline & S32 & $390.8,3.1721$ & 0.088 & $\mathrm{H}-3(\alpha) \rightarrow \mathrm{L}+1(\alpha)(\% 66)$ & & \\
\hline & S37 & $381.2,3.2524$ & 0.1239 & H-5 $(\beta) \rightarrow$ LUMO $(\beta)(\% 60)$ & & \\
\hline \multirow{8}{*}{$\mathrm{NiL}^{1}$} & S6 & $596.5,2.0783$ & 0.1244 & $\operatorname{HOMO}(\alpha) \rightarrow \operatorname{LUMO}(\alpha)(\% 69)$ & $300(17700)$ & LMCT \\
\hline & S7 & $574.9,2.1564$ & 0.0994 & $\mathrm{H}-1(\beta) \rightarrow \mathrm{LUMO}(\beta)(\% 54)$ & $410(766)$ & ${ }^{1} \mathrm{~A}_{1} \mathrm{~g} \rightarrow{ }^{1} \mathrm{~B}_{1} \mathrm{~g}$ \\
\hline & S23 & $416.3,2.9780$ & 0.0684 & H-2 (a) $\rightarrow$ LUMO $(\alpha)(\% 72)$ & $422(790)$ & ${ }^{1} \mathrm{~A}_{1} \mathrm{~g} \rightarrow{ }^{1} \mathrm{~B}_{2} \mathrm{~g}$ \\
\hline & S23 & $411.1,3.0155$ & 0.0327 & $\mathrm{H}-2(\beta) \rightarrow \mathrm{LUMO}(\beta)(\% 87)$ & & \\
\hline & S30 & $397.7,3.1169$ & 0.0631 & $\mathrm{H}-3(\beta) \rightarrow \mathrm{L}+1(\beta)(\% 66)$ & & \\
\hline & S36 & $386.9,3.2045$ & 0.0763 & $\operatorname{HOMO}(\beta) \rightarrow \mathrm{L}+4(\beta)(\% 60)$ & & \\
\hline & S38 & $382.5,3.2412$ & 0.0935 & H-6 $(\beta) \rightarrow$ LUMO $(\beta)(\% 34)$ & & \\
\hline & S42 & $376.5,3.2931$ & 0.1279 & $\mathrm{H}-4(\alpha) \rightarrow \mathrm{L}+2(\alpha)(\% 60)$ & & \\
\hline \multirow{7}{*}{$\mathrm{CuL}^{1}$} & S5 & $885.3,1.4005$ & 0.0007 & H-6 $(\beta) \rightarrow$ LUMO $(\beta)(\% 44)$ & $249(26100)$ & LMCT \\
\hline & S13 & $591.1,2.0973$ & 0.1081 & $\operatorname{HOMO}(\beta) \rightarrow \mathrm{L}+2(\beta)(\% 65)$ & $550(650)$ & ${ }^{2} \mathrm{~A}_{1} \mathrm{~g} \rightarrow{ }^{2} \mathrm{~B}_{1} \mathrm{~g}$ \\
\hline & S14 & $583.9,2.1233$ & 0.1707 & $\mathrm{H}-1(\beta) \rightarrow \mathrm{L}+3(\beta)(\% 59)$ & $760(1010)$ & ${ }^{2} \mathrm{~A}_{1} \mathrm{~g} \rightarrow{ }^{2} \mathrm{~B}_{2} \mathrm{~g}$ \\
\hline & S27 & $438.6,2.8264$ & 0.0272 & H-10 $(\beta) \rightarrow$ LUMO $(\beta)(\% 46)$ & & \\
\hline & S29 & $426.9,2.9041$ & 0.0309 & H-10 $(\beta) \rightarrow$ LUMO $(\beta)(\% 55)$ & & \\
\hline & S34 & $398.8,3.1088$ & 0.1639 & H-2 (a) $\rightarrow$ LUMO $(\alpha)(\% 63)$ & & \\
\hline & S50 & $359.3,3.4499$ & 0.127 & $\mathrm{H}-5(\alpha) \rightarrow \mathrm{L}+1(\alpha)(\% 47)$ & & \\
\hline \multirow{5}{*}{$\mathrm{CdL}^{1}$} & S2 & $568.9,2.1790$ & 0.1464 & H-1 $\rightarrow$ LUMO (\%69) & $319(9570)$ & $\mathrm{n} \rightarrow \pi^{*}$ \\
\hline & S5 & $386.4,3.2082$ & 0.0277 & $\mathrm{H}-1 \rightarrow \mathrm{L}+2(\% 59)$ & $350(13950)$ & LMCT \\
\hline & S7 & $376.6,3.2918$ & 0.6494 & H-3 $\rightarrow$ LUMO (\%45) & $389(24000)$ & LMCT \\
\hline & S9 & $373.2,3.3217$ & 0.1599 & H-2 $\rightarrow$ LUMO (\%48) & & \\
\hline & S17 & $308.2,4.0222$ & 0.2879 & H-7 $\rightarrow$ LUMO (\%51) & & \\
\hline
\end{tabular}
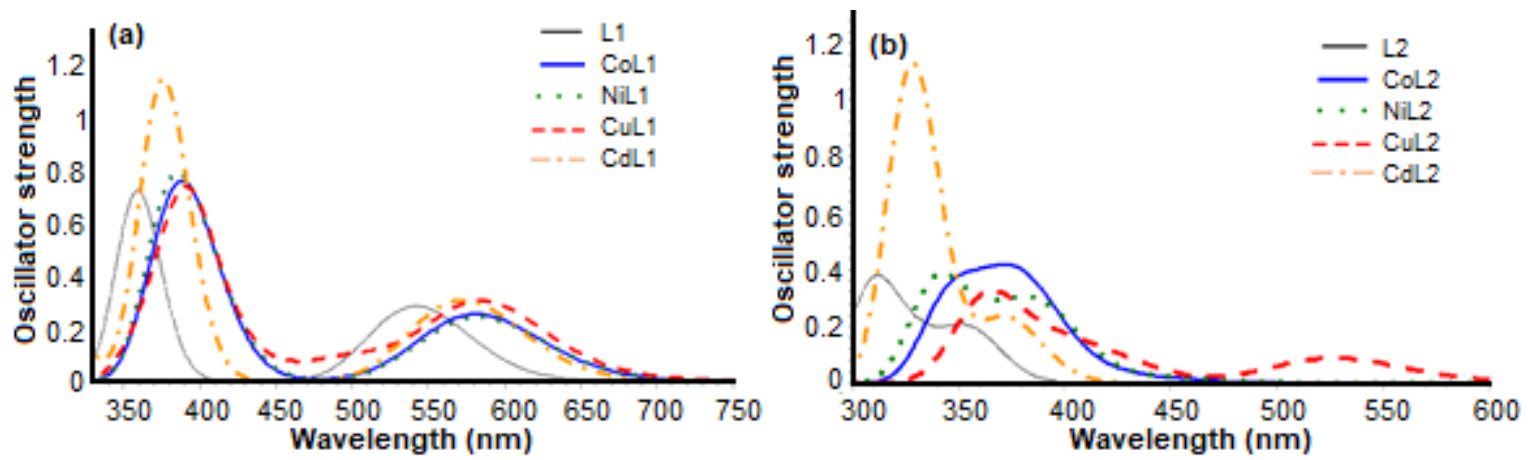

Fig 12. TDDFT calculations of UV-Vis spectra of the metal complexes of (a) $\mathrm{L}^{1}$ and (b) $\mathrm{L}^{2}$

As shown in Fig. 13 the HOMOs are of $\pi$ orbital localized on the different fragments of both $\mathrm{L}^{1}$ and $\mathrm{L}^{2}$. On the other hand, The LUMOs have localized more on $\pi^{*}$ orbital of the ligands and metal ions orbital play an insignificant role in the HOMOs and LUMOs. So, both these transitions are intra-ligand $\pi \rightarrow \pi^{*}$ in nature, Fig. 12 [27]. 
Table 5. The electronic transition calculated by TDDFT/CPCM method of $\mathrm{L}^{2}$ Schiff base and its metal complexes

\begin{tabular}{|c|c|c|c|c|c|c|}
\hline Compound & $\begin{array}{l}\text { Excited } \\
\text { state }\end{array}$ & $\lambda_{\text {cal }}(\mathrm{nm}),(\mathrm{eV})$ & $\begin{array}{l}\text { Oscillator } \\
\text { strength (f) }\end{array}$ & Key transition & $\begin{array}{c}\lambda_{\exp }(\mathrm{nm}), \\
\varepsilon \mathrm{L} \cdot \mathrm{mole}^{-1} \cdot \mathrm{cm}^{-1}\end{array}$ & Character \\
\hline \multirow{3}{*}{$\mathrm{L}^{2}$} & S2 & $354.7,3.4949$ & 0.1637 & HOMO $\rightarrow$ LUMO (\%62) & $366(10300)$ & $\mathrm{n} \rightarrow \pi^{*}$ \\
\hline & S3 & $327.8,3.7821$ & 0.1394 & H-1 $\rightarrow$ LUMO (\%65) & $330(21200)$ & LMCT \\
\hline & S4 & $309.1,4.0108$ & 0.3363 & $\mathrm{H}-2 \rightarrow \mathrm{LUMO}(\% 66)$ & & \\
\hline \multirow{6}{*}{$\mathrm{CoL}^{2}$} & S9 & $471.5,2.6295$ & 0.0015 & $\operatorname{HOMO}(\beta) \rightarrow \operatorname{LUMO}(\beta)(\% 100)$ & $290(30000)$ & $\pi \rightarrow \pi^{*}$ \\
\hline & S11 & $449.9,2.7558$ & 0.0013 & H-1 $(\alpha) \rightarrow$ LUMO $(\alpha)(\% 97)$ & $677(1220)$ & ${ }^{4} \mathrm{~T}_{1} \mathrm{~g} \rightarrow{ }^{4} \mathrm{~T}_{2} \mathrm{~g}(\mathrm{~F})$ \\
\hline & S19 & $423.0,2.9308$ & 0.0091 & $\mathrm{H}-1(\beta) \rightarrow \mathrm{L}+1(\beta)(\% 93)$ & $800(1010)$ & ${ }^{4} \mathrm{~T}_{1} \mathrm{~g} \rightarrow{ }^{4} \mathrm{~A}_{2} \mathrm{~g}(\mathrm{~F})$ \\
\hline & S29 & $388.9,3.1875$ & 0.1486 & $\mathrm{H}-4(\beta) \rightarrow \mathrm{L}+1(\beta)(\% 78)$ & & \\
\hline & S33 & $374.9,3.3070$ & 0.2096 & $\mathrm{H}-5(\beta) \rightarrow \mathrm{L}+1(\beta)(\% 73)$ & & \\
\hline & S49 & $344.9,3.5945$ & 0.272 & $\mathrm{H}-4(\beta) \rightarrow \mathrm{L}+2(\beta)(\% 56)$ & & \\
\hline \multirow{7}{*}{$\mathrm{NiL}^{2}$} & S10 & $460.4,2.6927$ & 0.0031 & $\mathrm{H}-1(\beta) \rightarrow \mathrm{LUMO}(\beta)(\% 83)$ & $233(27000)$ & $\pi \rightarrow \pi^{*}$ \\
\hline & S16 & $446.3,2.7777$ & 0.0095 & H-1 $(\alpha) \rightarrow$ LUMO $(\alpha)(\% 81)$ & $477(1033)$ & ${ }^{3} \mathrm{~A}_{12} \mathrm{~g} \rightarrow{ }^{3} \mathrm{~T}_{2} \mathrm{~g}(\mathrm{~F})$ \\
\hline & S30 & $394.5,3.1422$ & 0.1814 & $\mathrm{H}-4(\beta) \rightarrow \mathrm{L}+1(\beta)(\% 83)$ & $766(944)$ & ${ }^{3} \mathrm{~A}_{12} \mathrm{~g} \rightarrow{ }^{3} \mathrm{~T}_{1} \mathrm{~g}(\mathrm{~F})$ \\
\hline & S32 & $375.6,3.3007$ & 0.1191 & $\operatorname{HOMO}(\beta) \rightarrow \mathrm{L}+4(\beta)(\% 60)$ & & \\
\hline & S33 & $367.2,3.3758$ & 0.0405 & $\mathrm{H}-7(\alpha) \rightarrow \mathrm{L}+1(\alpha)(\% 57)$ & & \\
\hline & S46 & $344.0,3.6032$ & 0.146 & $\mathrm{H}-6(\beta) \rightarrow \mathrm{L}+1(\beta)(\% 51)$ & & \\
\hline & S49 & $336.4,3.6848$ & 0.1909 & $\mathrm{H}-7(\beta) \rightarrow \mathrm{LUMO}(\beta)(\% 53)$ & & \\
\hline \multirow{8}{*}{$\mathrm{CuL}^{2}$} & S5 & $648.1,1.9128$ & 0.0036 & H-6 $(\beta) \rightarrow$ LUMO $(\beta)(\% 44)$ & $306(15500)$ & $\mathrm{n} \rightarrow \pi^{*}$ \\
\hline & S8 & $527.2,2.3518$ & 0.0879 & $\operatorname{HOMO}(\beta) \rightarrow \mathrm{L}+2(\beta)(\% 65)$ & $390(31000)$ & LMCT \\
\hline & S16 & $421.3,2.9424$ & 0.0485 & $\mathrm{H}-1(\beta) \rightarrow \mathrm{L}+3(\beta)(\% 59)$ & $588(1300)$ & ${ }^{2} \mathrm{Eg} \rightarrow{ }^{2} \mathrm{~T}_{2} \mathrm{~g}$ \\
\hline & S32 & $400.4,3.0961$ & 0.0066 & $\mathrm{H}-10(\beta) \rightarrow$ LUMO $(\beta)(\% 46)$ & & \\
\hline & S28 & $386.6,3.2070$ & 0.0233 & H-10 $(\beta) \rightarrow$ LUMO $(\beta)(\% 55)$ & & \\
\hline & S39 & $366.0,3.3874$ & 0.0598 & $\mathrm{H}-2(\alpha) \rightarrow$ LUMO $(\alpha)(\% 63)$ & & \\
\hline & S44 & $354.6,3.4957$ & 0.0534 & $\mathrm{H}-5(\alpha) \rightarrow \mathrm{L}+1(\alpha)(\% 47)$ & & \\
\hline & S48 & $349.8,3.5437$ & 0.023 & $\mathrm{H}-4(\alpha) \rightarrow \mathrm{L}+2(\alpha)(\% 52)$ & & \\
\hline \multirow{5}{*}{$\mathrm{CdL}^{2}$} & S2 & $372.7,3.3261$ & 0.0914 & $\mathrm{HOMO} \rightarrow \mathrm{L}+2(\% 61)$ & $290(29400)$ & $\mathrm{n} \rightarrow \pi^{*}$ \\
\hline & S9 & $328.7,3.7714$ & 0.8854 & $\mathrm{H}-4 \rightarrow \mathrm{L}+1(\% 48)$ & $377(23890)$ & LMCT \\
\hline & S12 & $325.4,3.8100$ & 0.2257 & $\mathrm{H}-3 \rightarrow \mathrm{L}+2(\% 47)$ & & \\
\hline & S21 & $253.1,4.8968$ & 0.4177 & $\mathrm{H}-1 \rightarrow \mathrm{L}+4(\% 31)$ & & \\
\hline & S25 & $245.9,5.0402$ & 0.0636 & $\mathrm{H}-3 \rightarrow \mathrm{L}+3(\% 48)$ & & \\
\hline
\end{tabular}

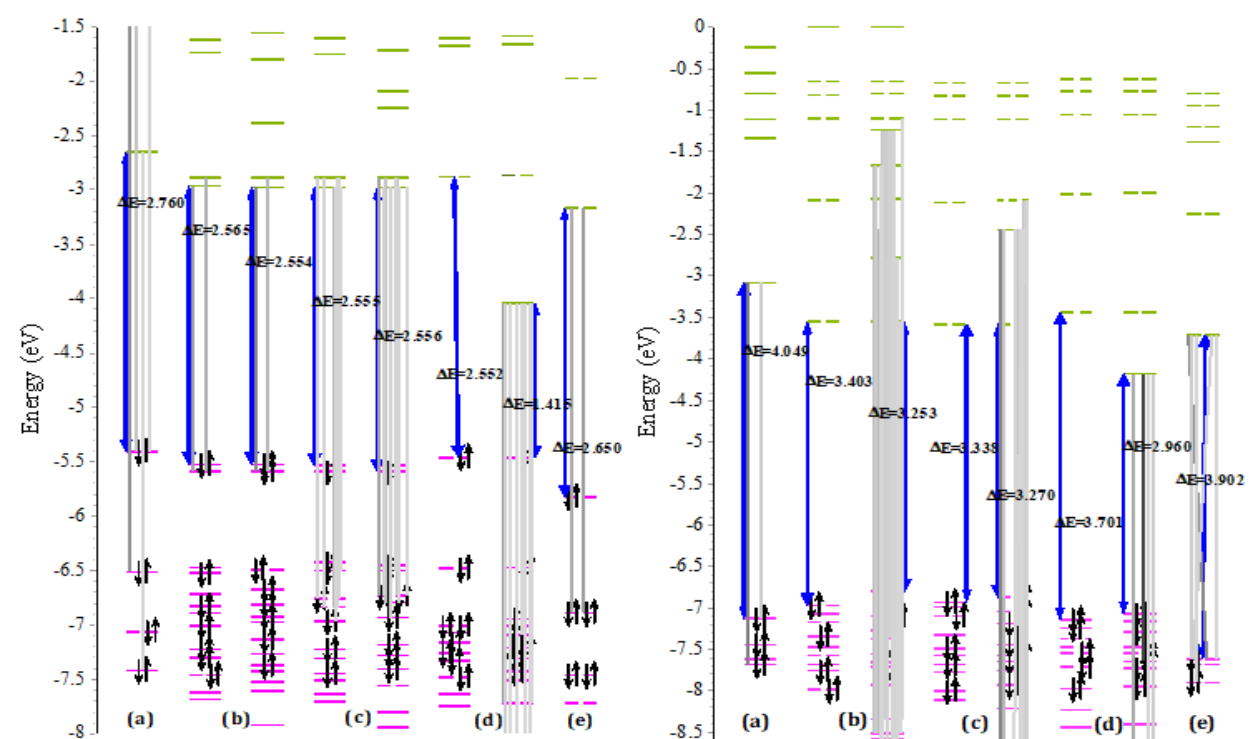

Fig 13. The molecular orbital diagram together with electronically excited states of (a) Schiff base $\mathrm{L}^{1}$ and $\mathrm{L}^{2}$, (b) CoL, (c) NiL, (d) CuL and (e) CdL in both $\alpha$ and $\beta$ spin states 


\section{- CONCLUSION}

According to the results obtained from elemental analysis, spectral, magnetic susceptibility measurements and the TG-DSC analyses, the octahedral geometry around cobalt, nickel, and copper(II) ions. As well as the vibration absorptions obtained from experimental FT-IR were in well-agreement of their theoretical obtained from DFT calculations then support the bidentate behaviors of the two Lewis bases $\mathrm{L}^{1}$ and $\mathrm{L}^{2}$. The optimized structures of all the synthesized complexes were shown in Fig. 11 and 12 and it is obvious that all complexes were octahedral except cadmium(II) which were tetrahedral and the TDDFT results investigate the experimental data related to spectral analyses.

\section{- ACKNOWLEDGMENTS}

We are so thankful for the members of chemistry department laboratories at Mustansiriyah University for carrying out the analysis of IR, UV and MS spectra. As well as we appreciate the facilities of Al-Bait University, Amman, Jordan for measuring of NMR spectra.

\section{- REFERENCES}

[1] Abdel-Shafi, A.A., Khalil, M.M.H., Abdalla, H.H., and Ramadan, R.M., 2002, Ruthenium, osmium and rhodium-2,3-bis(2'-pyridyl)quinoxaline complexes, Transition Met. Chem., 27 (1), 69-74.

[2] AL-Hashime, S.M., Sarhan, B.M., and Alazawi, S.A.S., 2007, Synthesis and studies of some mixed-ligand metal complexes containing benzotriazole with some other ligands, J. Al-Nahrain Univ., 10 (2), 82-88.

[3] Al-Jibouri, M.N., 2014, Template synthesis, characterization and antimicrobial study of new metal complexes from 2,6-diaminopyridine and 1,4dihydroquinoxalin-2,3-dione, Eur. Chem. Bull., 3 (4), 384-389.

[4] Appendino, G., Mercalli, E., Fuzzati, N., Arnoldi, L., Stavri, M., Gibbons, S., Ballero, M., and Maxia, A., 2004, Antimycobacterial coumarins from the Sardinian giant fennel (Ferulacommunis), J. Nat. Prod., 67 (12), 2108-2110.

[5] Badawy, M.A., Mohamed, G.G., Omar, M.M., Nassar, M.M., and Kamel, A.B., 2010, Synthesis, spectroscopic and thermal characterization of quinoxaline metal complexes, Eur. J. Chem., 1 (4), 282-288.

[6] Bejaoui, L., Rohlicek, J., and Hassen, R.B., 2018, New cobalt(II) complexes of '3-acetyl-4-hydroxy2H-chromene-2-one': Crystal structure and Hirshfeld surface analysis, fluorescence behaviour and antioxidant activity, J. Mol. Struct., 1173, 574582.

[7] Cotton, F.A., Wilkinson, G., Murillo, C.A., and Bochmann, M., 1999, Advanced Inorganic Chemistry, $6^{\text {th }}$ Ed., John Wiley \& Sons, Inc., New York, USA.

[8] Creaven, B.S., Egan, D.A., Kavanagh, K., McCann, M., Noble, A., Thati, B., and Walsh, M., 2006, Synthesis, characterization and antimicrobial activity of a series of substituted coumarin-3carboxylatosilver(I) complexes, Inorg. Chim. Acta, 359 (12), 3976-3984.

[9] Devienne, K.F., Raddi, M., Coelho, R.G., and Vilegas, W., 2005, Structure-antimicrobial activity of some natural isocoumarins and their analogues, Phytomedicine, 12 (5), 378-381.

[10] Emmanuel-Giota, A.A., Fylaktakidou, K.C., Litinas, K.E., Nicolaides, D.N., and Hadjipavlou-Litina, D.J., 2001, Synthesis and biological evaluation of several 3-(coumarin-4-yl)tetrahydroisoxazole and 3-(coumarin-4-yl)dihydropyrazole derivatives, $J$. Heterocycl. Chem., 38 (3), 717-722.

[11] Grazul, M., and Budzisz, E., 2009, Biological activity of metal ions complexes of chromones, coumarins and flavones, Coord. Chem. Rev., 253 (21-22), 25882598.

[12] Geary, W.J., 1971, The use of conductivity measurements in organic solvents for the characterisation of coordination compounds, Coord. Chem. Rev., 7 (1), 81-122.

[13] Frisch, M.J., Trucks, G.W., Schlegel, H.B., Scuseria, G.E., Robb, M.A., Cheeseman, J.R., Scalmani, G., Barone, V., Mennucci, B., Petersson, G.A., Nakatsuji, H., Caricato, M., Li, X., Hratchian, H.P., Izmaylov, A.F., Bloino, J., Zheng, G., Sonnenberg, J.L., Hada, M., Ehara, M., Toyota, K., Fukuda, R., 
Hasegawa, J., Ishida, M., Nakajima, T., Honda, Y., Kitao, O., Nakai, H., Vreven, T., Montgomery, Jr., J.A., Peralta, J.E., Ogliaro, F., Bearpark, M., Heyd, J.J., Brothers, E., Kudin, K.N., Staroverov, V.N., Kobayashi, R., Normand, J., Raghavachari, K., Rendell, A., Burant, J.C., Iyengar, S.S., Tomasi, J., Cossi, M., Rega, N., Millam, J.M., Klene, M., Knox, J.E., Cross, J.B., Bakken, V., Adamo, C., Jaramillo, J., Gomperts, R., Stratmann, R.E., Yazyev, O., Austin, A.J., Cammi, R., Pomelli, C., Ochterski, J.W., Martin, R.L., Morokuma, K., Zakrzewski, V.G., Voth, G.A., Salvador, P., Dannenberg, J.J., Dapprich, S., Daniels, A.D., Farkas, O., Foresman, J.B., Ortiz, J.V., Cioslowski, J., and Fox, D.J., 2009, Gaussian 09, Revision A.1, Gaussian, Inc., Wallingford CT.

[14] Lee, C., Yang, W., and Parr, R.G., 1988, Development of the Colle-Salvetti correlation-energy formula into a functional of the electron density, Phys. Rev. B: Condens. Matter, 37, 785-789.

[15] Tomasi, J., Mennucci, B., and Cammi, R., 2005, Quantum mechanical continuum solvation models, Chem. Rev., 105 (8), 2999-3094.

[16] Brown D.J., Ellman J.A., and Taylor, E.C., 2004, Quinoxalines, Supplement 2-Chemistry of Heterocyclic Compounds: A Series of Monographs, $1^{\text {st }}$ Ed., Wiley-Interscience, New York.

[17] Kostova, I., Bhatia, S., Grigorov, P., Balkansky, S., Parmar, V.S., Prasad, A.K., and Saso, L., 2011, Coumarins as antioxidants, Curr. Med. Chem., 18 (25), 3929-3951.

[18] Kulkarni, N.V., Kurdekar, G.S., Budagumpi, S., and Revankar, V.K., 2010, Spectroscopy, structure, and electrochemistry of transition metal complexes having $\left[\mathrm{M}_{2} \mathrm{~N}_{2} \mathrm{OS}_{2}\right]$ coordination sphere, J. Coord. Chem., 63 (18), 3301-3312.

[19] Liu, F., Martin-Mingot, A., Lecornué, F., Jouannetaud, M.P., Maresca, A., Thibaudeau, S., and Supuran, C.T., 2012, Carbonic anhydrases inhibitory effects of new benzenesulfonamides synthesized by using superacid chemistry, J. Enzyme Inhib. Med. Chem., 27 (6), 886-891.

[20] Cotton, F.A., Wilkinson, G., Murillo, C.A., and Bochmann, M., 1999, Advanced Inorganic Chemistry, $6^{\text {th }}$ Ed., John Wiley \& Sons, Inc., New York.

[21] Morse, G.E., Paton, A.S., Lough, A., and Bender, T.P., 2010, Chloro boron subphthalocyanine and its derivatives: dyes, pigments or somewhere in between?, Dalton Trans., 39 (16), 3915-3922.

[22] Shaker, S.A., Khaledi, H., and Ali, H.M., 2011, Spectroscopic investigations and physico-chemical characterization of newly synthesized mixed-ligand complexes of 2-methylbenzimidazole with metal ions, Chem. Pap., 65 (3), 299-307.

[23] Silverstein, R.M., and Bassler, G.C., 1962, Spectrometric identification of organic compounds, J. Chem. Educ., 39 (11), 546.

[24] Wang, C.J., Hsieh, Y.J., Chu, C.Y., Lin, Y.L., and Tseng, T.H., 2002, Inhibition of cell cycle progression in human leukemia HL-60 cells by esculetin, Cancer Lett., 183 (2), 163-168.

[25] Wright, J.S., Johnson, E.R., and DiLabio, G.A., 2001, Predicting the activity of phenolic antioxidants: Theoretical method, analysis of substituent effects, and application to major families of antioxidants, J. Am. Chem. Soc., 123 (6), 1173-1183.

[26] Shaffer, C.J., Martens, J., Marek, A., Oomens, J., and Tureček, F., 2016, Photoleucine survives backbone cleavage by electron transfer dissociation. A nearUV photodissociation and infrared multiphoton dissociation action spectroscopy study, J. Am. Soc. Mass. Spectrom., 27 (7), 1176-1185.

[27] Manna, S., Mistri, S., Bhunia, A., Paul, A., Zangrando, E., and Manna, S.C., 2017, Manganese(IV) complex with a polydentate Schiff base ligand: Synthesis, crystal structure, TDDFT calculation, electronic absorption and EPR spectral study, J. Coord. Chem., 70 (2), 296-313. 